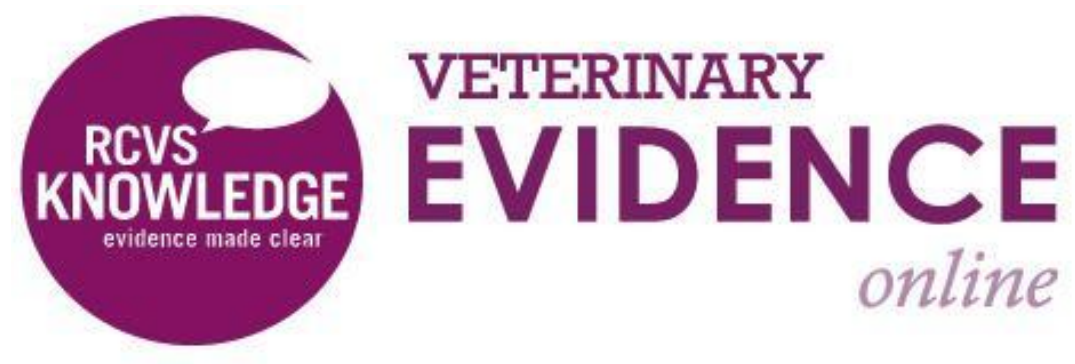

\title{
The evidence behind the diagnostic investigation of canine idiopathic epilepsy.
}

\section{A Knowledge Summary by}

Marios Charalambous DVM GPCert(Neuro) RSci MRSB MRCVS ${ }^{1 *}$ David Brodbelt MA VetMB PhD DVA DipECVAA MRCVS ${ }^{2}$ Holger Volk DVM PhD DipECVN FHEA MRCVS ${ }^{2}$

\footnotetext{
${ }^{1}$ University College London

${ }^{2}$ Royal Veterinary College

Corresponding Author (marios.charalambous.15@ucl.ac.uk)
} 


\section{Clinical bottom line}

There remains until recently an overall lack of clarity for the practical criteria for the diagnosis of canine idiopathic epilepsy. Signalment and an interictal neurological examination are vital for the diagnosis of idiopathic epilepsy. Despite the current insufficient evidence, the emergence of new diagnostic methods, such as cerebrospinal fluid and/or serum biomarkers, advanced functional neuroimaging techniques and electroencephalography, is likely to change the diagnostic approach in canine epilepsy in the near future.

\section{Question}

In dogs, are biomarker and advanced imaging methods superior to signalment and an interictal neurological examination for the diagnosis of epilepsy?

\section{Clinical scenario}

A 5 years old $17 \mathrm{~kg}$ German Shepherd intact male dog manifested generalized tonic-clonic seizures one year ago. In the last two months the dog manifested five episodes. The dog is normal between the episodes, idiopathic epilepsy is suspected. You wonder what the best diagnostic investigation to confirm the presumed idiopathic epilepsy would be.

\section{Summary of the evidence}

\begin{tabular}{|r|l|}
\hline \multicolumn{2}{|l|}{ Ghormie (2015) } \\
\hline Sopulation: & Dogs with idiopathic (Tier II) and structural epilepsy. \\
\hline Intervention details: & $\begin{array}{l}\text { 99 dogs, n=99 } \\
\text { Dogs } \geq 5 \text { years of age with a diagnosis of idiopathic or structural } \\
\text { epilepsy were retrieved from medical files. Classification of dogs } \\
\text { based on age was performed. The prevalence of idiopathic and } \\
\text { structural epilepsy and the proportion of subjects with secondary } \\
\text { epilepsy due to neoplasia and other disorder was assessed. The } \\
\text { sensitivity and specificity of abnormal neurological signs in cases } \\
\text { with structural epilepsy were also evaluated. }\end{array}$ \\
\hline Study design: & Retrospective case series \\
\hline Outcome studied: & $\begin{array}{l}\text { Objective: To classify the origin of epilepsy and assess the } \\
\text { neurological defects during clinical examination as a predictor of } \\
\text { structural epilepsy in dogs } \geq 5 \text { years of age }\end{array}$ \\
\hline &
\end{tabular}




\begin{tabular}{|r|l|}
\hline Main findings: & It was shown that lack of deficits on neurologic examination does \\
(relevant to PICO question): & $\begin{array}{l}\text { not exclude the possibility of intracranial lesions. Neurologic deficits } \\
\text { found during clinical examination had } 74 \% \text { sensitivity and } 62 \% \\
\text { specificity to predict structural epilepsy }\end{array}$ \\
\hline Limitations: & Retrospective case series \\
\hline
\end{tabular}

\begin{tabular}{|c|c|}
\hline \multicolumn{2}{|l|}{ Van Meervenne (2015) } \\
\hline Population: & Dogs with idiopathic epilepsy (Tier I confidence level). \\
\hline Sample size: & 45 dogs, $n=45$ (intact females only) \\
\hline Intervention details: & $\begin{array}{l}\text { Medical records of intact female dogs diagnosed with epilepsy. The } \\
\text { stage of the estrous cycle as reported either by theowner or the } \\
\text { veterinarian at the time of the first seizure was noted. Unclear } \\
\text { diagnostic procedures for idiopathic epilepsy }\end{array}$ \\
\hline Study design: & Retrospective case series \\
\hline Outcome studied: & $\begin{array}{l}\text { Objective: To evaluate whether there is an association between } \\
\text { onset of seizures and the estrous cycle in intact bitches with } \\
\text { idiopathic epilepsy and whether a pattern to the onset of seizures } \\
\text { could be recognized }\end{array}$ \\
\hline $\begin{array}{l}\text { Main findings: } \\
\text { (relevant to PICO question): }\end{array}$ & $\begin{array}{l}\text { The findings suggest an association between estrus and } \\
\text { onset of seizures in intact bitches with presumptive } \\
\text { idiopathic epilepsy. } \\
\text { - Two hormonally based patterns could be recognized: one } \\
\text { during heat and one during a specific time point at the end } \\
\text { of diestrus. } \\
\text { - This could be explained by the proconvulsive effects of } \\
\text { estrogen or loss of protective effect against seizures of } \\
\text { progesterone, respectively }\end{array}$ \\
\hline Limitations: & $\begin{array}{l}\text { - Retrospective case series. } \\
\text { - Tier I confidence level for diagnosing idiopathic epilepsy for } \\
\text { some cases. }\end{array}$ \\
\hline
\end{tabular}

\begin{tabular}{|r|l|}
\hline \multicolumn{2}{|l|}{ Armasu (2014) } \\
\hline Sopulation: & Dogs with idiopathic (Tier II) and structural epilepsy \\
\hline Intervention details: & $\begin{array}{l}\text { 258 dogs, n=258 } \\
\text { Data including age, sex, neuter status, time until diagnosis, age of } \\
\text { seizure onset in years, type of seizure, seizure symmetry, seizure } \\
\text { severity, interictal neurological deficits, MRI changes and side effects } \\
\text { associated with antiepileptic drugs were extracted from medical } \\
\text { files. }\end{array}$ \\
\hline Study design: & Retrospective case series \\
\hline Outcome studied: & $\begin{array}{l}\text { Objective:_To assess the influence of the aforementioned factors, } \\
\text { such as age, sex, interictal neuro exam, seizure type etc. on the } \\
\text { likelihood of structural or functional brain disease, via a thorough } \\
\text { history taking process and interictal neurological examination }\end{array}$ \\
\hline
\end{tabular}




\begin{tabular}{|r|r|}
\hline Main findings: & - $\begin{array}{l}\text { This study demonstrated that breed and age alone should } \\
\text { not be used to distinguish between idiopathic epilepsy and } \\
\text { symmetrical or asymmetrical structural brain lesions. }\end{array}$ \\
& $\begin{array}{l}\text { selevant to PICO question): } \\
\text { It was found that } 89 \% \text { of dogs with idiopathic epilepsy had } \\
\text { an age of seizure onset }<6 \text { years and } 84 \% \text { of these had a } \\
\text { normal neurological examination. }\end{array}$ \\
\hline Limitations: & $\begin{array}{l}\text { Retrospective case series study. } \\
\text { - However, multinomial statistics were used which were good } \\
\text { in filtering out the non-significant. }\end{array}$ \\
\hline
\end{tabular}

\begin{tabular}{|c|c|}
\hline \\
\hline \multicolumn{2}{|c|}{\begin{tabular}{l|l} 
Population: & $\begin{array}{l}\text { Dogs with SRMA, MUO, } \\
\text { dogs. }\end{array}$
\end{tabular}} \\
\hline Sample size: & 141 dogs, $n=141$ \\
\hline Intervention details: & $\begin{array}{l}\text { 3 investigation groups, } 1 \text { Control group. } 1 \text { group with healthy dogs } \\
\text { - Investigation group 1: SRMA dogs } n=51 \text { ( } 25 \text { received no } \\
\text { medication and the remaining received steroids) } \\
\text { - Investigation group 2: MUO dogs } \mathrm{n}=27 \text { (16 received no } \\
\text { medication and the remaining received steroids) } \\
\text { - Investigation group 3: IVVD dogs } \mathrm{n}=36 \text { (16 received no } \\
\text { medication and the remaining received steroids) } \\
\text { - Control group: Idiopathic epilepsy dogs } \mathrm{n}=21 \\
\text { - Healthy dogs: The dogs in this group compared only to } \\
\text { idiopathic epilepsy group } \mathrm{n}=6\end{array}$ \\
\hline Study design: & $\begin{array}{l}\text { Open-labeled, non-randomised, controlled experimental animal } \\
\text { study. }\end{array}$ \\
\hline Outcome studied: & $\begin{array}{l}\text { Objective: Chemokines such as MIP-3B/CCL19 are important factors } \\
\text { in the mechanism of cell migration and pathogenesis of central } \\
\text { nervous system (CNS) inflammatory reactions. The hypothesis of this } \\
\text { study is that CCL19, also known as MIP- } 3 \beta \text {, is involved in the } \\
\text { pathogenesis of inflammatory and non-inflammatory CNS diseases } \\
\text { of dogs }\end{array}$ \\
\hline $\begin{array}{l}\text { Main findings: } \\
\text { (relevant to PICO question): }\end{array}$ & $\begin{array}{l}\text { CCL19 CSF concentrations were markedly elevated in } \\
\text { patients affected with the neuroinflammatory diseases } \\
\text { steroid-responsive meningitis arteritis (SRMA) and } \\
\text { meningoencephalitis of unknown etiology (MUO)(compared } \\
\text { to idiopathic epilepsy group) and showed a strong } \\
\text { correlation with the CSF cell count. } \\
\text { - The comparison between IE and healthy animals showed } \\
\text { significant difference in CCL19 concentrations which } \\
\text { suggests that inflammatory processes might be involved in } \\
\text { IE pathogenesis }\end{array}$ \\
\hline
\end{tabular}




\begin{tabular}{|l|l|}
\hline Limitations: & $\begin{array}{l}\text { - Non-blinded and non-randomised. } \\
\text { - }\end{array}$ \\
& Tier I confidence level for diagnosing idiopathic epilepsy for \\
& some cases. \\
& Since only a small number of neurologically normal dogs \\
& were available for evaluation, further studies with a larger \\
& cohort of dogs focusing on idiopathic epilepsy in comparison \\
& to healthy dogs are indicated before definite \\
& recommendations. \\
\hline
\end{tabular}

\begin{tabular}{|c|c|}
\hline \multicolumn{2}{|l|}{ Freds $\emptyset$ (2014) } \\
\hline Population: & $\begin{array}{l}\text { Dogs with idiopathic(Tier I or insufficient level of confidence) and } \\
\text { structural epilepsy }\end{array}$ \\
\hline Sample size: & 102 dogs, $n=102$ \\
\hline Intervention details: & $\begin{array}{l}\text { - One hundred and two client owned dogs; } 78 \text { dogs with } \\
\text { idiopathic epilepsy and } 24 \text { dogs with structural epilepsy. } \\
\text { - A retrospective hospital based study with follow-up. Dogs } \\
\text { diagnosed with epilepsy between } 2002 \text { and } 2008 \text { were } \\
\text { enrolled in the study. Owners were interviewed by } \\
\text { telephone using a structured questionnaire addressing } \\
\text { epilepsy status, treatment, death/alive, and cause of death. }\end{array}$ \\
\hline Study design: & Retrospective case series, questionnaire \\
\hline Outcome studied: & $\begin{array}{l}\text { Objective: To investigate risk factors for survival and duration of } \\
\text { survival in a population of dogs with idiopathic or structural epilepsy }\end{array}$ \\
\hline $\begin{array}{l}\text { Main findings: } \\
\text { (relevant to PICO question): }\end{array}$ & $\begin{array}{l}\text { Neutered male dogs with idiopathic epilepsy had a significant } \\
\text { shorter survival (median: } 38.5 \text { months) compared to intact male } \\
\text { dogs (median: } 71 \text { months). }\end{array}$ \\
\hline Limitations: & $\begin{array}{l}\text { - Retrospective case series. } \\
\text { - Tier I or insufficient or confidence level for diagnosing } \\
\text { idiopathic epilepsy }\end{array}$ \\
\hline
\end{tabular}

\begin{tabular}{|c|c|}
\hline \multicolumn{2}{|l|}{ Hasegawa (2014) } \\
\hline Population: & $\begin{array}{l}\text { Dogs with idiopathic (insufficient level of confidence) and structural } \\
\text { epilepsy and healthy dogs }\end{array}$ \\
\hline Sample size: & N/A \\
\hline Intervention details: & $\begin{array}{l}2 \text { investigation group, } 1 \text { Control group. } \\
\text { - Investigation group 1: Idiopathic epileptic dogs } \\
\text { - Investigation group 2: Structural epileptic dogs } \\
\text { - Control group: Healthy dogs } \\
\text { Gas chromatography-mass spectrometry (GC-MS)-based metabolic } \\
\text { profiling of CSF and multivariate data analysis were performed }\end{array}$ \\
\hline Study design: & $\begin{array}{l}\text { Open-labeled, non-randomised, controlled experimental animal } \\
\text { study }\end{array}$ \\
\hline
\end{tabular}




\begin{tabular}{|c|c|}
\hline Outcome studied: & $\begin{array}{l}\text { Objective: To explore canine epilepsy diagnostic biomarkers in the } \\
\text { cerebrospinal fluid (CSF). }\end{array}$ \\
\hline $\begin{array}{l}\text { Main findings: } \\
\text { (relevant to PICO question): }\end{array}$ & $\begin{array}{l}\text { Profiles for dogs with idiopathic epilepsy differed } \\
\text { significantly from those of healthy controls and subjects with } \\
\text { structural epilepsy. } \\
\text { - Among } 60 \text { identified metabolites, the levels of } 20 \text { differed } \\
\text { significantly among the three groups. Glutamic acid was } \\
\text { significantly increased in idiopathic epilepsy, and some } \\
\text { metabolites including ascorbic acid were changed in both } \\
\text { forms of epilepsy. } \\
\text { These findings show that metabolic profiles of CSF differ } \\
\text { between idiopathic and symptomatic epilepsy and that } \\
\text { metabolites including glutamic acid and ascorbic acid in CSF } \\
\text { may be useful for diagnosis of canine epilepsy. }\end{array}$ \\
\hline Limitations: & $\begin{array}{l}\text { - Only abstract was retrieved. } \\
\text { - } \quad \text { Non-blinded and non-randomised. } \\
\text { - Insufficient confidence level for diagnosing idiopathic } \\
\text { epilepsy for some cases }\end{array}$ \\
\hline
\end{tabular}

\begin{tabular}{|c|c|}
\hline \multicolumn{2}{|l|}{ Merbl (2014) } \\
\hline Population: & $\begin{array}{l}\text { Dogs with idiopathic epilepsy (Tier I level of confidence) and healthy } \\
\text { dogs }\end{array}$ \\
\hline Sample size: & $\begin{array}{l}\text { Unclear number of dogs with seizures. Number of healthy dogs was } \\
12 .\end{array}$ \\
\hline Intervention details: & $\begin{array}{l}1 \text { Investigation group, } 1 \text { Control group. } \\
\text { - Treatment group: Dogs with seizures. Unclear number. } \\
\text { - Control_group: Healthy dogs } n=12\end{array}$ \\
\hline Study design: & Blinded, randomized, controlled experimental animal study \\
\hline Outcome studied: & $\begin{array}{l}\text { Objective: To investigate whether dogs with seizures have higher } \\
\text { cerebrospinal interleukin- } 6 \text { (IL-6) and tumor necrosis factor- } \alpha \text { (TNF- } \\
\alpha) \text { concentrations compared to dogs with no seizures }\end{array}$ \\
\hline $\begin{array}{r}\text { Main findings: } \\
\text { (relevant to PICO question): }\end{array}$ & $\begin{array}{l}\text { Higher TNF- } \alpha \text { and IL- } 6 \text { concentration in the CSF of dogs with } \\
\text { naturally occurring seizures were detected. }\end{array}$ \\
\hline Limitations: & $\begin{array}{l}\text { - Unclear number of dogs with seizures. } \\
\text { - Tier I confidence level for diagnosing idiopathic epilepsy for } \\
\text { some cases }\end{array}$ \\
\hline
\end{tabular}

\begin{tabular}{|c|c|}
\hline Viitmaa (2014) & \\
\hline Population: & Dogs with idiopathic epilepsy (Tier III). \\
\hline Sample size: & 17 dogs, $n=17$ \\
\hline Intervention details: & $\begin{array}{l}1 \text { investigation group, } 1 \text { Control group. } \\
\text { - Investigation group: Dogs with idiopathic epilepsy } n=11 \\
\text { - Control group: Healthy dogs } n=6\end{array}$ \\
\hline
\end{tabular}




\begin{tabular}{|c|c|}
\hline Study design: & Blinded, non-randomised controlled experimental animal study \\
\hline Outcome studied: & $\begin{array}{l}\text { Objective: In human epileptic patients, changes in cerebral glucose } \\
\text { utilization can be detected 2-deoxy-2-[18F] fluoro-d-glucose positron } \\
\text { emission tomography (FDG-PET). The purpose of this prospective } \\
\text { study was to determine whether epileptic dogs might show similar } \\
\text { findings. Electroencephalography (EEG) was also performed. }\end{array}$ \\
\hline $\begin{array}{l}\text { Main findings: } \\
\text { (relevant to PICO question): }\end{array}$ & $\begin{array}{l}\text { - Findings were significantly associated with epileptic dogs } \\
\text { compared to healthy ones by the use of both methods. } \\
\text { Both diagnostic tests were consensual and specific (100\%) } \\
\text { for occipital findings, but EEG had a lower sensitivity for } \\
\text { detecting lateralized foci than FDG-PET. } \\
\text { - Findings supported the use of FDG-PET as a diagnostic test } \\
\text { for dogs with suspected idiopathic epilepsy. }\end{array}$ \\
\hline Limitations: & $\begin{array}{l}\text { - Non-randomised } \\
\text { - Low number of dogs. } \\
\text { - Breed specific changes found might not be applicable for } \\
\text { other breeds. } \\
\text { - The test was not evaluated in dogs with generalized seizures }\end{array}$ \\
\hline
\end{tabular}

\begin{tabular}{|c|c|}
\hline Creevy (2013) & \\
\hline Population: & Dogs with idiopathic epilepsy (Tier II) \\
\hline Sample size: & 17 dogs, $n=17$ \\
\hline Intervention details: & $\begin{array}{l}2 \text { investigation groups, } 1 \text { Control group. } \\
\text { - Investigation group 1: Idiopathic epileptic dogs with no } \\
\text { abnormal MRI findings } n=8 \\
\text { - Investigation group 2: Idiopathic epileptic dogs with hyper } \\
\text { intense areas in the limbic system detected by means of } \\
\text { T2W MRI } n=4 \\
\text { - Control group: Healthy dogs } n=5\end{array}$ \\
\hline Study design: & $\begin{array}{l}\text { Open-labeled, non-randomised, controlled experimental animal } \\
\text { study }\end{array}$ \\
\hline Outcome studied: & $\begin{array}{l}\text { Objective: To investigate differences in cerebrospinal fluid (CSF) } \\
\text { concentrations of excitatory and inhibitory neurotransmitters in } \\
\text { dogs with idiopathic epilepsy with and without T2-weighted (T2W) } \\
\text { MRI hyperintense areas in the limbic system }\end{array}$ \\
\hline $\begin{array}{l}\text { Main findings: } \\
\text { (relevant to PICO question): }\end{array}$ & $\begin{array}{l}\text { - No significant difference was evident between glutamate } \\
\text { concentrations in CSF of dogs with idiopathic epilepsy and } \\
\text { with and without hyperintense areas detected by means of } \\
\text { T2W MRI, but glutamate, though, concentrations typically } \\
\text { were higher in CSF of dogs with idiopathic epilepsy and MRI } \\
\text { hyperintense areas. } \\
\text { - Concentrations of GABA in CSF were higher in dogs } \\
\text { idiopathic epilepsy with MRI hyperintense areas than in dogs } \\
\text { with idiopathic epilepsy and normal MRI and in latter dogs } \\
\text { than in healthy dogs. }\end{array}$ \\
\hline
\end{tabular}




\begin{tabular}{|l|l|}
\hline Limitations: & $\begin{array}{l}\text { - Non-blinded and non-randomised. } \\
\end{array}$ \\
& - Low study population. \\
\hline
\end{tabular}

\begin{tabular}{|c|c|}
\hline \multicolumn{2}{|l|}{ Gesell (2013) } \\
\hline Population: & Dogs with idiopathic epilepsy (Tier II). \\
\hline Sample size: & 56 dogs, $n=56$ \\
\hline Intervention details: & $\begin{array}{l}1 \text { investigation group, } 1 \text { Control group. } \\
\text { - Investigation group: Dogs with idiopathic epilepsy } n=40 \\
\text { - Control group: Healthy dogs } n=16\end{array}$ \\
\hline Study design: & Retrospective case series \\
\hline Outcome studied: & $\begin{array}{l}\text { Objective: The hypothesis was that cerebrospinal fluid (CSF) } \\
\text { concentrations of the endocannabinoids anandamide (AEA) and 2- } \\
\text { arachidonoyl glycerol ( } 2 A G \text { ) are altered in epileptic dogs. } \\
\text { Concentrations of AEA and total AG (sum of } 2 A G \text { and } 1 A G \text { ) were } \\
\text { measured in dogs with idiopathic epilepsy and healthy control dogs } \\
\text { using liquid chromatography combined with tandem mass } \\
\text { spectrometry }\end{array}$ \\
\hline $\begin{array}{l}\text { Main findings: } \\
\text { (relevant to PICO question): }\end{array}$ & $\begin{array}{l}\text { - An elevation of CSF AEA concentrations was found in dogs } \\
\text { with idiopathic epilepsy compared to control group. } \\
\text { - The highest AEA concentrations were found in dogs with } \\
\text { severe seizures and a long disease history. It was suggested } \\
\text { that the activation of the AEA may serve as a counter- } \\
\text { mechanism in order to regulate the seizure-threshold in } \\
\text { epilepsy and that can alter or be altered by seizure activity; } \\
\text { so further, prospective studies are warranted to investigate } \\
\text { this mechanism }\end{array}$ \\
\hline Limitations: & Retrospective case series \\
\hline
\end{tabular}

\begin{tabular}{|c|c|}
\hline \multicolumn{2}{|l|}{ Viitmaa (2013) } \\
\hline Population: & Dogs with idiopathic epilepsy (insufficient level of confidence). \\
\hline Sample size: & 2069 dogs, $n=2069$ \\
\hline Intervention details: & $\begin{array}{l}\text { From } 2003 \text { to 2004, questionnaires ( } n=5,960 \text { ) were sent to all } \\
\text { owners of } 1 \text { - to } 10 \text {-year-old Finnish Spitz dogs (FSDs) in Finland. } \\
\text { Phone interviews were performed } 1 \text { to } 2 \text { years later }\end{array}$ \\
\hline Study design: & Prospective epidemiological study-questionnaires. \\
\hline Outcome studied: & $\begin{array}{l}\text { Objective: To determine the phenotype, inheritance characteristics, } \\
\text { and risk factors for idiopathic epilepsy in FSDs. }\end{array}$ \\
\hline $\begin{array}{l}\text { Main findings: } \\
\text { (relevant to PICO question): }\end{array}$ & $\begin{array}{l}\text { - Estimated prevalence of idiopathic epilepsy was } 5.36 \% \\
\text { (111/2,069 of FSDs that were still alive). } \\
\text { - Males were predisposed to IE. The median age of onset was } \\
3 \text { years (range, } 0.6 \text { to } 10 \text { years). The median seizure } \\
\text { frequency was } 2 \text { seizures/year (range, } 0.5 \text { to } 48\end{array}$ \\
\hline
\end{tabular}




\begin{tabular}{|l|l|l|}
\hline & $\begin{array}{l}\text { seizures/year) The majority (85\%) of the seizures had a focal } \\
\text { onset, and 54\% were characterized as generalized } \\
\text { secondary. }\end{array}$ \\
\hline Limitations: & $\begin{array}{l}\text { Non-blinded, non-randomised and uncontrolled. } \\
\text { - Insufficient confidence level for diagnosing idiopathic } \\
\text { epilepsy for some cases. }\end{array}$ \\
- Potential subjective assessment mainly by owners and \\
secondary by investigators.
\end{tabular}

\begin{tabular}{|c|c|}
\hline \multicolumn{2}{|l|}{ Akos (2012) } \\
\hline Population: & Dogs with idiopathic (Tier II) and structural epilepsy \\
\hline Sample size: & 40 dogs, $n=40$ \\
\hline Intervention details: & $\begin{array}{l}\text { - Dogs with structural and idiopathic epilepsy. } \\
\text { - Propofol was used for chemical restraint in all dogs and } \\
\text { electroencephalogram (EEG) was performed }\end{array}$ \\
\hline Study design: & $\begin{array}{l}\text { Open-labeled, non-randomised, controlled experimental animal } \\
\text { study }\end{array}$ \\
\hline Outcome studied: & $\begin{array}{l}\text { Objective: To identify interictal epileptiform discharges via EEG in a } \\
\text { group of dogs with seizures of known aetiology and } \\
\text { in dogs with idiopathic epilepsy. }\end{array}$ \\
\hline $\begin{array}{l}\text { Main findings: } \\
\text { (relevant to PICO question): }\end{array}$ & $\begin{array}{l}\text { - Interictal EEG examinations of propofol-anaesthetised dogs } \\
\text { suffering from idiopathic and structural epilepsy rarely show } \\
\text { epileptic discharges. } \\
\text { - This, the diagnostic value of such EEGs in the work-up for } \\
\text { epilepsy seems to be low as epileptic discharges were } \\
\text { unlikely to be detected. }\end{array}$ \\
\hline Limitations: & Non-blinded and non-randomised \\
\hline
\end{tabular}

\begin{tabular}{|c|c|}
\hline$(2012)$ & \\
\hline Population: & Dogs with idiopathic (Tier III) and structural epilepsy \\
\hline Sample size: & 89 dogs, $n=89$ \\
\hline Intervention details: & $\begin{array}{l}\text { - } 2 \text { investigation comparison groups: } \\
\text { Investigation group 1: Dogs with idiopathic epilepsy } n=61 \\
\text { Investigation group 2: Dogs with structural epilepsy } n=28 \\
\text { - Electroencephalograms were recorded using five subdermal } \\
\text { EEG electrodes (F3, F4, CZ, O1 and O2). } \\
\text { - All } 89 \text { EEGs were analysed visually and } 61 \text { were also } \\
\text { evaluated quantitatively with fast fourier transformations }\end{array}$ \\
\hline Study design: & $\begin{array}{l}\text { Open-labeled, non-randomised, controlled experimental animal } \\
\text { study }\end{array}$ \\
\hline Outcome studied: & $\begin{array}{l}\text { Objective: To investigate the diagnostic value of interictal short time } \\
\text { electroencephalographic (EEG) recordings in epileptic dogs under } \\
\text { general anaesthesia with propofol and the muscle relaxant }\end{array}$ \\
\hline
\end{tabular}




\begin{tabular}{|c|c|}
\hline & rocuronium bromide in epileptic dogs. \\
\hline $\begin{array}{l}\text { Main findings: } \\
\text { (relevant to PICO question): }\end{array}$ & $\begin{array}{l}\text { - Interictal paroxysmal epileptiform activity was found in } 25 \% \\
\text { of idiopathic and in } 29 \% \text { of symptomatic epileptic dogs. } \\
\text { - Despite the use of activation techniques, the results showed } \\
\text { that short time EEG recordings in epileptic dogs can detect } \\
\text { interictal epileptic activity in less than one third of all } \\
\text { seizuring dogs. } \\
\text { - Therefore, it was not a useful diagnostic method when used } \\
\text { during the interictal periods of epileptic dogs }\end{array}$ \\
\hline Limitations: & Non-blinded and non-randomised. \\
\hline
\end{tabular}

\begin{tabular}{|c|c|}
\hline \multicolumn{2}{|l|}{ Calvo (2012) } \\
\hline Population: & Dogs with idiopathic epilepsy (insufficient level of evidence) \\
\hline Sample size: & 56 dogs, $n=56$ \\
\hline Intervention details: & $\begin{array}{l}2 \text { investigation groups, } 1 \text { Control group. } 1 \text { group with healthy dogs } \\
\text { - Investigation group 1: Dogs with idiopathic epilepsy that had } \\
\text { seizures within } 24 \text { hours from blood or liquor collection } \\
\text { seizures } n=17 \\
\text { - Investigation group 2: Dogs with idiopathic epilepsy that } \\
\text { had after } 24 \text { to } 120 \text { hours from blood or liquor collection } \\
\text { seizures within } 24 \mathrm{~h} n=16 \\
\text { - Control group: Healthy dogs } n=23\end{array}$ \\
\hline Study design: & $\begin{array}{l}\text { Open-labelled, non-randomised, controlled experimental animal } \\
\text { study }\end{array}$ \\
\hline Outcome studied: & $\begin{array}{l}\text { Objective: To evaluate C-reactive protein concentration in blood of } \\
\text { patients with idiopathic epilepsy and verify if the protein can be } \\
\text { considered a biomarker to help its diagnose. }\end{array}$ \\
\hline $\begin{array}{l}\text { Main findings: } \\
\text { (relevant to PICO question): }\end{array}$ & $\begin{array}{l}\text { - Seizures associated with idiopathic epilepsy promote an } \\
\text { acute phase response characterized by an increase of blood } \\
\text { C reactive protein concentrations within } 24 \text { hours, and after } \\
\text { this period C reactive protein concentrations declined due to } \\
\text { the liberation of inflammatory mediators by the brain and } \\
\text { muscle contractions. } \\
\text { - Therefore blood and C reactive protein concentrations can } \\
\text { be used as a biomarker to differentiate idiopathic epilepsy } \\
\text { from other seizures causes. }\end{array}$ \\
\hline Limitations: & $\begin{array}{l}\text { - Non-blinded and non-randomised. } \\
\text { - The ELISA technique for C reactive protein liquor analysis } \\
\text { needs to be validated. } \\
\text { - Insufficient confidence level for diagnosing idiopathic } \\
\text { epilepsy for some cases. }\end{array}$ \\
\hline
\end{tabular}

de la Fuente (2012

Population: $\quad$ Dogs with various neurological disorders, included idiopathic epilepsy (Tier I and insufficient level of confidence) 


\begin{tabular}{|c|c|}
\hline Sample size: & 169 dogs, $n=169$ \\
\hline Intervention details: & $\begin{array}{l}\text { Dogs with neurological disorders included } 11 \text { with steroid- } \\
\text { responsive meningitis-arteritis (SRMA), } 37 \text { with other inflammatory } \\
\text { neurological diseases (INF), } 38 \text { with neoplasia affecting the central } \\
\text { nervous system (NEO), } 28 \text { with spinal compressive disorders (SCC), } \\
15 \text { with idiopathic epilepsy, and } 40 \text { with non inflammatory } \\
\text { neurological disorders (NON-INF), } 7 \text { dogs with systemic } \\
\text { inflammatory diseases without central nervous system involvement } \\
\text { (SID), and } 7 \text { healthy (control group) Beagles were included in the } \\
\text { study }\end{array}$ \\
\hline Study design: & Prospective observational study \\
\hline Outcome studied: & $\begin{array}{l}\text { Objective: To investigate fibrinolytic activity in the CSF of dogs with } \\
\text { neurological disorders by measuring cerebrospinal fluid (CSF) D- } \\
\text { dimer concentration }\end{array}$ \\
\hline $\begin{array}{l}\text { Main findings: } \\
\text { (relevant to PICO question): }\end{array}$ & $\begin{array}{l}\text { All dogs with idiopathic epilepsy as well as dogs with systematic non- } \\
\text { neurological inflammatory diseases and controls had undetectable } \\
\text { concentrations of D-dimers in the CSF }\end{array}$ \\
\hline Limitations: & $\begin{array}{l}\text { - Non-blinded and non-randomised. } \\
\text { - Tier I and insufficient confidence level for diagnosing } \\
\text { idiopathic epilepsy for some cases }\end{array}$ \\
\hline
\end{tabular}

\begin{tabular}{|c|c|}
\hline Seppälä (2012) & \\
\hline Population: & Dogs with idiopathic epilepsy (Tier III) \\
\hline Sample size: & 307 dogs, $n=307$ \\
\hline Intervention details: & $\begin{array}{l}\text { Investigators collected } 159 \text { cases and } 148 \text { controls and confirmed } \\
\text { the presence of idiopathic epilepsy through epilepsy questionnaires } \\
\text { and clinical examinations via advance imaging (MRI) and } \\
\text { electroencephalograms(EEGs). }\end{array}$ \\
\hline Study design: & Epidemiological study-questionnaires \\
\hline Outcome studied: & $\begin{array}{l}\text { Objective: To study the clinical and genetic background of epilepsy in } \\
\text { Belgian Shepherds. }\end{array}$ \\
\hline $\begin{array}{l}\text { Main findings: } \\
\text { (relevant to PICO question): }\end{array}$ & Genetic predispose of Belgian Shepherd dogs. \\
\hline Limitations: & Non-blinded and non-randomised \\
\hline
\end{tabular}

\begin{tabular}{|c|c|}
\hline \multicolumn{2}{|l|}{ Weber (2012) } \\
\hline Population: & $\begin{array}{l}\text { Dogs with various neurological disorders, included idiopathic } \\
\text { epilepsy (insufficient level of confidence) }\end{array}$ \\
\hline Sample size: & 328 dogs, $n=328$ \\
\hline Intervention details: & $\begin{array}{l}\text { The dogs were assigned to seven different groups: } \\
\text { - Steroid-responsive meningitis-arteritis (SRMA), }\end{array}$ \\
\hline
\end{tabular}




\begin{tabular}{|c|c|}
\hline & $\begin{array}{l}\text { - } \text { intervertebral disc disease (IVDD) } \\
\text { - neoplasia of the central nervous system (N) } \\
\text { - idiopathic epilepsy } \\
\text { - } \text { bacterial meningoencephalomyelitis (BM) } \\
\text { - meningoencephalomyelitis of unknown origin (MUE) } \\
\text { - healthy dogs }\end{array}$ \\
\hline Study design: & Retrospective case series study \\
\hline Outcome studied: & $\begin{array}{l}\text { Objective: To evaluate the glucose ratio (glucose level in the } \\
\text { cerebrospinal fluid [CSF]/blood glucose level) as a quickly available } \\
\text { marker for detecting bacterialmeningoencephalomyelitis and } \\
\text { compared to other diseases. }\end{array}$ \\
\hline $\begin{array}{l}\text { Main findings: } \\
\text { (relevant to PICO question): }\end{array}$ & $\begin{array}{l}\text { - The median of the CSF-glucose level (mmol/I) and the } \\
\text { median of the glucose ratio in the SRMA group displayed the } \\
\text { lowest values and differed significantly from the CSF-glucose } \\
\text { levels of dogs in the groups IVDD, N, idiopathic epilepsy and } \\
\text { healthy dogs (CSF-glucose level: } p<0.01 \text {; glucose ratio: } \\
\mathrm{p}<0.05) \text {. } \\
\text { - Therefore, the CSF-glucose level and glucose ratio was not } \\
\text { useful for supporting the diagnoses idiopathic epilepsy } \\
\text { according to the findings of this study }\end{array}$ \\
\hline Limitations: & $\begin{array}{l}\text { - } \text { Retrospective case series } \\
\text { - } \quad \text { Subjective assessment } \\
\text { - Insufficient confidence level for diagnosing idiopathic } \\
\text { epilepsy for some cases. }\end{array}$ \\
\hline
\end{tabular}

Browand-Stainback (2011)

\begin{tabular}{|c|c|}
\hline Population: & Dogs with idiopathic epilepsy (insufficient level of confidence) \\
\hline Sample size: & 211 dogs and cats, $n=211$ \\
\hline Intervention details: & $\begin{array}{l}\text { - Epileptic seizures in } 211 \text { canine and feline patients } \\
\text { diagnosed with idiopathic epilepsy were evaluated for } \\
\text { temporal significance in relation to the lunar cycle. } \\
\text { - Seizure counts were compared among each of the eight } \\
\text { individual lunar phases, among each of eight exact lunar } \\
\text { phase dates, and by percent of lunar illumination using } \\
\text { generalized estimating equations. }\end{array}$ \\
\hline Study design: & Retrospective case series \\
\hline Outcome studied: & $\begin{array}{l}\text { Objective: To investigate the potential connection between canine } \\
\text { and feline epileptic seizures and the lunar cycle. }\end{array}$ \\
\hline $\begin{array}{l}\text { Main findings: } \\
\text { (relevant to PICO question): }\end{array}$ & $\begin{array}{l}\text { No statistical significance was found in any of these comparisons } \\
\text { excluding a relationship between the onset of epileptic seizures and } \\
\text { the phases of the moon. }\end{array}$ \\
\hline Limitations: & $\begin{array}{l}\text { - Only abstract was retrieved. } \\
\text { - Retrospective case series. }\end{array}$ \\
\hline
\end{tabular}




\begin{tabular}{|c|c|}
\hline \multicolumn{2}{|l|}{ Ekenstedt (2011) } \\
\hline Population: & Dogs with idiopathic epilepsy (insufficient level of confidence). \\
\hline Sample size: & 34 dogs, $n=34$ \\
\hline Intervention details: & $\begin{array}{l}\text { Candidate genes known to be involved in human epilepsy, along } \\
\text { with selected additional genes in the same gene families that are } \\
\text { involved in murine epilepsy or are expressed in neural tissue, were } \\
\text { examined in populations of affected and unaffected dogs. } \\
\text { Microsatellite markers in close proximity to each candidate gene } \\
\text { were genotyped and subjected to two-point linkage in Vizslas, and } \\
\text { association analysis in ESS, GSMD and Beagles. }\end{array}$ \\
\hline Study design: & Experimental study/genetic analysis \\
\hline Outcome studied: & $\begin{array}{l}\text { Objective: To investigate if there are simple genetic bases for IE in } \\
\text { some purebred dog breeds, specifically in Vizslas, English Springer } \\
\text { Spaniels (ESS), Greater Swiss Mountain Dogs (GSMD), and Beagles, } \\
\text { and that the gene(s) responsible may, in some cases, be the same as } \\
\text { those already discovered in humans. }\end{array}$ \\
\hline $\begin{array}{l}\text { Main findings: } \\
\text { (relevant to PICO question): }\end{array}$ & $\begin{array}{l}\text { - Most of these candidate genes were not significantly } \\
\text { associated with idiopathic epilepsy in these four dog breeds, } \\
\text { while a few genes remained inconclusive. } \\
\text { - Other genes not included in this study may still be causing } \\
\text { monogenic idiopathic epilepsy in these breeds or, like many } \\
\text { cases of human idiopathic epilepsy, the disease in dogs may } \\
\text { be likewise polygenic }\end{array}$ \\
\hline Limitations: & $\begin{array}{l}\text { - Only abstract was available. } \\
\text { - Insufficient confidence level for diagnosing idiopathic } \\
\text { epilepsy for some cases }\end{array}$ \\
\hline
\end{tabular}

\begin{tabular}{|c|c|}
\hline \multicolumn{2}{|l|}{ Goncalves (2010) } \\
\hline Population: & Dogs with idiopathic epilepsy (Tier I-II) \\
\hline Sample size: & 124 dogs, $n=124$ \\
\hline Intervention details: & $\begin{array}{l}3 \text { investigation groups in comparison } \\
\text { Dogs were divided into three groups depending on the time interval } \\
\text { between their last seizure and the cerebrospinal fluid (CSF) } \\
\text { collection: } \\
\text { - up to two days (group 1) } \\
\text { - between three and seven days (group 2) } \\
\text { - >seven days (group 3). } \\
\text { The dogs were also divided into two groups based on whether or not } \\
\text { cluster seizures occurred before CSF collection. }\end{array}$ \\
\hline Study design: & Open-labeled, non-randomised experimental animal study. \\
\hline Outcome studied: & $\begin{array}{l}\text { Objective: To determine the effect of seizures on CSF composition of } \\
\text { dogs with idiopathic epilepsy. }\end{array}$ \\
\hline
\end{tabular}




\begin{tabular}{|l|l|l|}
\hline Main findings: & - $\begin{array}{l}\text { A significant association was observed between the total } \\
\text { nucleated cell count (TNCC) and the time interval between } \\
\text { the last seizure and the collection of the CSF, the longer the } \\
\text { time interval, the lower the TNCC. }\end{array}$ \\
& $\begin{array}{l}\text { There was no association observed between time interval } \\
\text { and CSF protein concentration; and no association was also } \\
\text { found between the current of cluster seizures and either } \\
\text { TNCC CSF or protein concentration. }\end{array}$ \\
& $\begin{array}{l}\text { It was suggested that alterations in the CSF TNCC can be } \\
\text { induced by seizures in dogs. }\end{array}$ \\
\hline Limitations: & $\begin{array}{l}\text { Non-blinded and non-randomized } \\
\text { Tier I confidence level for diagnosing idiopathic epilepsy for } \\
\end{array}$ \\
& some cases \\
\hline
\end{tabular}

\begin{tabular}{|c|c|}
\hline \\
\hline \multicolumn{2}{|l|}{$\begin{array}{l}\text { Wessmann (2010) } \\
\text { Population: }\end{array}$} \\
\hline Sample size: & 359 dogs, $n=359$ \\
\hline Intervention details: & $\begin{array}{l}\text { The frequency of surface epithelial cells in } 359 \text { canine CSF samples } \\
\text { was analyzed for } 5 \text { disease groups: central nervous system (CNS) } \\
\text { neoplasia, CNS compression, CNS inflammation, idiopathic epilepsy, } \\
\text { and miscellaneous diseases. Groups were also combined into those } \\
\text { with and without expected meningeal involvement. }\end{array}$ \\
\hline Study design: & Retrospective case series \\
\hline Outcome studied: & $\begin{array}{l}\text { Objective: To identify the frequency of surface epithelial cells } \\
\text { in CSF from dogs with neurologic disease was investigated along } \\
\text { with the potential association with age, specific type of CNS disease, } \\
\text { and CSF total nucleated cell count (TNCC) and protein concentration }\end{array}$ \\
\hline $\begin{array}{l}\text { Main findings: } \\
\text { (relevant to PICO question): }\end{array}$ & $\begin{array}{l}\text { - Surface epithelial cells were found in idiopathic epilepsy in } \\
\text { - } \\
\text { Significant associations between surface epithelial cell } \\
\text { presence in CSF and age, disease type, CSF TNCC, and CSF } \\
\text { protein concentration were not found. } \\
\text { - The presence of surface epithelial cells was not related to a } \\
\text { specific disease group or CSF changes in the studied } \\
\text { population. Thus, the presence of surface epithelial cells } \\
\text { should be interpreted carefully, as it could represent an } \\
\text { incidental finding in CSF specimens. }\end{array}$ \\
\hline Limitations: & $\begin{array}{l}\text { - Retrospective case series. } \\
\text { - Tier I confidence level for diagnosing idiopathic epilepsy for } \\
\text { some cases. }\end{array}$ \\
\hline
\end{tabular}

Fujiwara (2008)

Population: $\quad$ Dogs with various neurological disorders, including idiopathic 


\begin{tabular}{|c|c|}
\hline & epilepsy (insufficient level of confidence). \\
\hline Sample size: & 310 dogs, $n=310$ \\
\hline Intervention details: & $\begin{array}{l}\text { Blood serum samples were randomly collected from } 310 \\
\text { dogs } \\
\text { - The dogs were divided into three groups: NME cases (group } \\
\text { 1), non-NME CNS disease cases (group 2) and non-CNS } \\
\text { disease cases (group 3) } \\
\text { - Twenty-six (26) serum samples from clinically healthy dogs } \\
\text { were also included for comparison (control group) }\end{array}$ \\
\hline Study design: & Open-labeled, randomised controlled experimental animal study \\
\hline Outcome studied: & $\begin{array}{l}\text { Objective: To determine whether serum autoantibodies against glial } \\
\text { fibrillary acidic protein (GFAP) can be used for diagnosing canine } \\
\text { necrotizing meningoencephalitis (NME) and secondarily, other } \\
\text { diseases. }\end{array}$ \\
\hline $\begin{array}{l}\text { Main findings: } \\
\text { (relevant to PICO question): }\end{array}$ & $\begin{array}{l}\text { Dogs with Chari malformation and idiopathic epilepsy, } \\
\text { prostate cancer, insulinoma, malignant lymphoma, pituitary- } \\
\text { dependent hyperadrenocorticism, myasthenia gravis and } \\
\text { polyarthritis also exhibited high values. } \\
\text { - Thus, serum GFAP autoantibodies might be non-specific and } \\
\text { not of use for diagnosing NME or any of the diseases } \\
\text { mentioned (including idiopathic epilepsy) }\end{array}$ \\
\hline Limitations: & $\begin{array}{l}\text { - Non-blinded } \\
\text { - Insufficient confidence level for diagnosing idiopathic } \\
\text { epilepsy }\end{array}$ \\
\hline
\end{tabular}

\begin{tabular}{|c|c|}
\hline \multicolumn{2}{|l|}{ Kloene (2008) } \\
\hline Population: & Dogs with idiopathic epilepsy (Tier I) \\
\hline Sample size: & 365 dogs, $n=365$ \\
\hline Intervention details: & $\begin{array}{l}\text { Questionnaires and metabolic screening tests were used. Dogs were } \\
\text { also included in a large pedigree, which was subdivided into ten } \\
\text { smaller subsets }\end{array}$ \\
\hline Study design: & Prospective study-epidimiological - pedigree analysis \\
\hline Outcome studied: & $\begin{array}{l}\text { Objective: To identify a genetic basis for the condition in Border } \\
\text { Terrier dogs. }\end{array}$ \\
\hline $\begin{array}{l}\text { Main findings: } \\
\text { (relevant to PICO question): }\end{array}$ & $\begin{array}{l}\text { - About } 70 \% \text { of the affected dogs showed generalised } \\
\text { seizures, and in about } 45 \% \text { of the cases the seizures had a } \\
\text { tonic character. } \\
\text { - About } 80 \% \text { of the animals did not lose consciousness during } \\
\text { the seizures. } \\
\text { - The median age of the Border Terriers included in the study } \\
\text { was } 3.73 \text { years and the median age at seizure onset was } 3.15 \\
\text { years. } \\
\text { - The inspection of the pedigrees showed that the majority of } \\
\text { affected Border Terriers were descended from unaffected }\end{array}$ \\
\hline
\end{tabular}




\begin{tabular}{|c|c|}
\hline & $\begin{array}{l}\text { parents. Matings among two unaffected animals or affected } \\
\text { and unaffected animals resulted always in affected and } \\
\text { unaffected offspring }\end{array}$ \\
\hline Limitations: & $\begin{array}{l}\text { - Tier I confidence level for diagnosing idiopathic epilepsy } \\
\text { - Risk of subjective assessment }\end{array}$ \\
\hline
\end{tabular}

\begin{tabular}{|c|c|}
\hline \\
\hline \multicolumn{2}{|c|}{$\begin{array}{l}\text { Pákozdy (2008) } \\
\qquad \begin{array}{l|l}\text { Population: } & \begin{array}{l}\text { Dogs with idiopathic (Tier II level of confidence) and structural } \\
\text { epilepsy }\end{array}\end{array}\end{array}$} \\
\hline $\begin{array}{c}\text { Sample size: } \\
\end{array}$ & 240 dogs, $n=240$ \\
\hline Intervention details: & $\begin{array}{l}\text { Data search was performed. Seizure aetiologies were classified as } \\
\text { idiopathic epilepsy }(n=115) \text { and structural epilepsy }(n=125) \text {. }\end{array}$ \\
\hline Study design: & Retrospective case series \\
\hline Outcome studied: & $\begin{array}{l}\text { Objective: To examine the underlying aetiology and to compare } \\
\text { idiopathic epilepsy with symptomatic epilepsy concerning } \\
\text { signalment, history, ictal pattern, clinical and neurological findings. }\end{array}$ \\
\hline $\begin{array}{l}\text { Main findings: } \\
\text { (relevant to PICO question): }\end{array}$ & $\begin{array}{l}\text { - Status epilepticus, cluster seizures, partial seizures, } \\
\text { vocalisation during seizure and impaired neurological status } \\
\text { were more readily seen with symptomatic epilepsy. } \\
\text { - If the first seizure occurred between one and five years of } \\
\text { age or the seizures occurred during resting condition, the } \\
\text { diagnosis was more likely idiopathic epilepsy than structural } \\
\text { epilepsy. } \\
\text { - No correlation of seizures with oestrus, full moon and stress } \\
\text { or excitement could be found. } \\
\text { Golden Retrievers and Beagles were the most common } \\
\text { reported pure breeds suffering from idiopathic epilepsy. }\end{array}$ \\
\hline Limitations: & Retrospective case series \\
\hline
\end{tabular}

\begin{tabular}{|r|l|}
\hline \multicolumn{2}{|l|}{ Smith (2008) } \\
\hline Sopulation: & $\begin{array}{l}\text { Dogs with seizures and idiopathic epilepsy (Tier II level of } \\
\text { confidence) }\end{array}$ \\
\hline Intervention details: & $\begin{array}{l}76 \text { dogs, } \mathrm{n}=76 \\
\text { In this study the prevalence of clinically significant magnetic } \\
\text { resonance imaging (MRI) abnormalities was determined in two } \\
\text { groups of interictally normal dogs, those younger than 6 years and } \\
\text { those older than 6 years of age }\end{array}$ \\
\hline Study design: & Open-labeled, non-randomised controlled clinical study \\
\hline Outcome studied: & $\begin{array}{l}\text { Objective: To determine the prevalence of positive MR findings in } \\
\text { dogs with no evidence of forebrain dysfunction on interictal } \\
\text { neurological examination and to determine whether it is affected by } \\
\text { patient age }\end{array}$ \\
\hline
\end{tabular}




\begin{tabular}{|r|l|}
\hline $\begin{array}{r}\text { Main findings: } \\
\text { (relevant to PICO question): }\end{array}$ & $\begin{array}{l}\text { A low likelihood of revealing an underlying lesion by MRI, in } \\
\text { seizuring dogs }<6 \text { years of age with an unremarkable interictal } \\
\text { neurological examination was found }\end{array}$ \\
\hline Limitations: & Non-blinded and non-randomised \\
\hline
\end{tabular}

\begin{tabular}{|c|c|}
\hline \multicolumn{2}{|l|}{ Jokinen (2007) } \\
\hline Population: & Dogs with seizures and idiopathic epilepsy (Tier II) \\
\hline Sample size: & 25 dogs, $n=25$ \\
\hline Intervention details: & $\begin{array}{l}\text { - Puppies (Lagotto Romagnolo) dogs presented on the } \\
\text { hospital for examination and investigation of their simple or } \\
\text { complex focal seizures } \\
\text { - Clinical and diagnostic evaluations of affected dogs were } \\
\text { conducted, including electromyography, } \\
\text { electroencephalography, blood test, advance imaging and } \\
\text { other testing }\end{array}$ \\
\hline Study design: & $\begin{array}{l}\text { Uncontrolled experimental animal study-prospective case series } \\
\text { study }\end{array}$ \\
\hline Outcome studied: & $\begin{array}{l}\text { Objective: To identify idiopathic juvenile epilepsies with benign } \\
\text { outcomes in Lagotto Romagnolo dogs. }\end{array}$ \\
\hline $\begin{array}{l}\text { Main findings: } \\
\text { (relevant to PICO question): }\end{array}$ & $\begin{array}{l}\text { - Seizures in puppies began at } 5 \text { to } 9 \text { weeks of age and usually } \\
\text { resolved spontaneously by } 8 \text { to } 13 \text { weeks. Those with the } \\
\text { most severe seizures also had signs of neurologic disease } \\
\text { between these seizures, including generalized ataxia and } \\
\text { hypermetria. } \\
\text { - There were no abnormalities in routine laboratory } \\
\text { screenings of blood, urine, and cerebrospinal fluid. } \\
\text { Electromyography, brainstem auditory-evoked potentials, } \\
\text { and magnetic resonance imaging revealed no specific and } \\
\text { consistent abnormalities. } \\
\text { - Pedigree analysis suggests an autosomal recessive mode of } \\
\text { inheritance. } \\
\text { - For the cases that had simple or complex focal seizures and } \\
\text { cerebellar lesions, it represents a newly recognized epileptic } \\
\text { syndrome in dogs }\end{array}$ \\
\hline Limitations: & Non-blinded, uncontrolled study \\
\hline
\end{tabular}

\begin{tabular}{|c|c|}
\hline \multicolumn{2}{|l|}{ Licht (2007) } \\
\hline Population: & Dogs with idiopathic epilepsy (Tier I level of confidence). \\
\hline Sample size: & 90 dogs, $n=90$ \\
\hline Intervention details: & $\begin{array}{l}1 \text { investigation group, } 1 \text { control group } \\
\text { - Investigation group: } 30 \text { dogs with probable idiopathic } \\
\text { epilepsy } \\
\text { - Control group: } 60 \text { dogs without any history of seizures }\end{array}$ \\
\hline
\end{tabular}




\begin{tabular}{|c|c|}
\hline & $\begin{array}{l}\text { Researchers contacted owners to determine whether dogs had ever } \\
\text { had any seizures and, if so, the nature of any such seizures and any } \\
\text { potential underlying causes. } \\
\text { To determine the mode of inheritance, segregation analyses were } \\
\text { designed to allow the family to be analyzed as a whole, as opposed } \\
\text { to as nuclear families. Competing models of inheritance were } \\
\text { compared statistically for their ability to explain the data. }\end{array}$ \\
\hline Study design: & Prospective case series study \\
\hline Outcome studied: & $\begin{array}{l}\text { Objective: To determine clinical characteristics and mode of } \\
\text { inheritance of seizures in a family of Standard Poodles }\end{array}$ \\
\hline $\begin{array}{l}\text { Main findings: } \\
\text { (relevant to PICO question): }\end{array}$ & $\begin{array}{l}\text { Results suggested that in this family of Standard Poodles, } \\
\text { idiopathic epilepsy was inherited as a simple recessive } \\
\text { autosomal trait with complete or almost complete } \\
\text { penetrance. Seizures often had focal, as opposed to } \\
\text { generalized, onsets, and it was not uncommon for seizures } \\
\text { to begin after } 5 \text { years of age. } \\
\text { - In addition, } 28(93 \%) \text { had focal onset seizures with or } \\
\text { without secondary generalization. Median age of onset was } \\
3.7 \text { years. }\end{array}$ \\
\hline Limitations: & $\begin{array}{l}\text { - Tier I confidence level for diagnosing idiopathic epilepsy } \\
\text { - Part of the assessment of the study was subjective }\end{array}$ \\
\hline
\end{tabular}

\begin{tabular}{|c|c|}
\hline \multicolumn{2}{|l|}{ Casal (2006) } \\
\hline Population: & Dogs with idiopathic epilepsy (insufficient level of confidence). \\
\hline Sample size: & 796 dogs, $n=796$ \\
\hline Intervention details: & $\begin{array}{l}\text { Clinical data and pedigrees from closely related Irish Wolfhounds } \\
\text { were collected retrospectively and analysed }\end{array}$ \\
\hline Study design: & Retrospective case series study. Pedigree analysis \\
\hline Outcome studied: & $\begin{array}{l}\text { Objective: The aim of this study was to identify inheritance } \\
\text { characteristics in Irish Wolfhounds. }\end{array}$ \\
\hline $\begin{array}{l}\text { Main findings: } \\
\text { (relevant to PICO question): }\end{array}$ & $\begin{array}{l}\text { - Idiopathic epilepsy was diagnosed, by exclusion of other } \\
\text { causes for seizures, in } 146 \text { ( } 18.3 \%) \text { of } 796 \text { Irish Wolfhounds. } \\
\text { The first seizure occurred by the age of } 3 \text { years in } 73 \% \text { of all } \\
\text { dogs. Males were more commonly affected than females } \\
\text { (61.6\% versus } 38.4 \%) \text {, with males having a later average age } \\
\text { of seizure onset } \\
\text { - It was assumed that the complex pattern of inheritance } \\
\text { observed is autosomal recessive, with incomplete } \\
\text { penetrance and male dogs at increased risk }\end{array}$ \\
\hline Limitations: & $\begin{array}{l}\text { - Retrospective case series. } \\
\text { - Insufficient confidence level for diagnosing idiopathic } \\
\text { epilepsy }\end{array}$ \\
\hline
\end{tabular}




\begin{tabular}{|c|c|}
\hline \multicolumn{2}{|l|}{ Pákozdy (2006) } \\
\hline Population: & $\begin{array}{l}\text { Dogs with seizures in general and idiopathic epilepsy (Tier II level of } \\
\text { confidence). }\end{array}$ \\
\hline Sample size: & 13 dogs, $n=13$ \\
\hline Intervention details: & $\begin{array}{l}\text { All boxers with seizures within the last } 7 \text { years were included in this } \\
\text { retrospective study }\end{array}$ \\
\hline Study design: & Retrospective case series study \\
\hline Outcome studied: & $\begin{array}{l}\text { Objective: The aim of this study was to evaluate the aetiology of } \\
\text { seizures in Boxers of our patient-index and to compare it with } \\
\text { literature data }\end{array}$ \\
\hline $\begin{array}{l}\text { Main findings: } \\
\text { (relevant to PICO question): }\end{array}$ & $\begin{array}{l}\text { - Only } 2 \text { boxers were diagnosed with idiopathic epilepsy } \\
\text { - The use of blood tests and MRI is recommended, } \\
\text { independently of age, history and physical-neurologic } \\
\text { examination indicating idiopathic epilepsy }\end{array}$ \\
\hline Limitations: & $\begin{array}{l}\text { - Retrospective case series } \\
\text { - Low study population }\end{array}$ \\
\hline
\end{tabular}

\begin{tabular}{|c|c|}
\hline \\
\hline \multicolumn{2}{|c|}{ Population: Dogs with seizures } \\
\hline Sample size: & 14 dogs, $n=14$ \\
\hline Intervention details: & $\begin{array}{l}1 \text { investigation group, } 1 \text { control group } \\
\text { - Investigation group: Finnish Spitz dogs with focal seizures } \\
\mathrm{n}=11 \\
\text { - Control group: Healthy dogs. } \mathrm{n}=3\end{array}$ \\
\hline Study design: & $\begin{array}{l}\text { Open-labelled, non-randomized controlled experimental animal } \\
\text { study }\end{array}$ \\
\hline Outcome studied: & $\begin{array}{l}\text { Objective: To investigate the magnetic resonance imaging findings in } \\
\text { Finnish spitz dogs with focal epilepsy }\end{array}$ \\
\hline $\begin{array}{l}\text { Main findings: } \\
\text { (relevant to PICO question): }\end{array}$ & $\begin{array}{l}\text { - General clinical and neurological examinations, blood } \\
\text { examination, urinalysis, cerebrospinal fluid examination, } \\
\text { electroencephalography (EEG), and magnetic resonance } \\
\text { imaging (MRI) of the brain were performed on all dogs. } \\
\text { - On EEG examination, focal epileptic activity was found in } 7 \\
\text { of } 11 \text { dogs (64\%), and generalized epileptic activity was } \\
\text { observed in } 4 \text { of } 11 \text { dogs ( } 36 \%) \text {. MRI (performed with } 1.5 \mathrm{~T} \\
\text { equipment) detected changes in } 1 \text { epileptic dog. } \\
\text { - Finnish Spitz dogs with focal seizures suffered from } \\
\text { idiopathic epilepsy and had non-detectable findings on MRI } \\
\text { or pathology }\end{array}$ \\
\hline Limitations: & $\begin{array}{l}\text { - Non-blinded and non-randomized } \\
\text { - Low study population }\end{array}$ \\
\hline
\end{tabular}




\begin{tabular}{|c|c|}
\hline \multicolumn{2}{|l|}{ Patterson (2005) } \\
\hline \multicolumn{2}{|c|}{ Population: $\quad$ Dogs with idiopathic epilepsy (Tier I-II). } \\
\hline Sample size: & 119 dogs, $n=119$ \\
\hline Intervention details: & $\begin{array}{l}\text { Forty-five dogs with idiopathic epilepsy and } 74 \text { siblings and their } \\
\text { respective parents were included in the analysis }\end{array}$ \\
\hline Study design: & Prospective case series study \\
\hline Outcome studied: & $\begin{array}{l}\text { Objective: To determine clinical characteristics and mode of } \\
\text { inheritance of idiopathic epilepsy in English Springer Spaniels }\end{array}$ \\
\hline $\begin{array}{l}\text { Main findings: } \\
\text { (relevant to PICO question): }\end{array}$ & $\begin{array}{l}\text { - Median age at the onset of seizures was } 3 \text { years; however, } 9 \\
\text { (20\%) dogs were between } 5 \text { and } 6 \text { years old at the time of } \\
\text { the onset of seizures. Twenty-one dogs ( } 47 \% \text { ) had } \\
\text { generalized seizures, and } 24 \text { ( } 53 \% \text { ) had focal onset seizures } \\
\text { In English Springer Spaniels, idiopathic epilepsy segregated } \\
\text { in a manner that is consistent with partially penetrant } \\
\text { autosomal recessive inheritance (ie, a single major locus with } \\
\text { modifying genes) or polygenic inheritance }\end{array}$ \\
\hline Limitations: & $\begin{array}{l}\text { Tier I confidence level for diagnosing idiopathic epilepsy in many } \\
\text { cases }\end{array}$ \\
\hline
\end{tabular}

\begin{tabular}{|c|c|}
\hline \multicolumn{2}{|l|}{ Ellenberger (2004) } \\
\hline \multicolumn{2}{|c|}{ Population: Dogs with idiopathic epilepsy (insufficient level of confidence). } \\
\hline Sample size: & 149 dogs, $n=149$ \\
\hline Intervention details: & $\begin{array}{l}\text { - Thirty-five Labrador Retrievers with genetic epilepsy, } 94 \text { non- } \\
\text { Labrador Retrievers with idiopathic epilepsy, and } 20 \text { control } \\
\text { dogs } \\
\text { - Collection of CSF was performed }>72 \text { h after the occurrence } \\
\text { of seizures. Cerebrospinal fluid concentrations of gamma - } \\
\text { aminobutyric acid (GABA), glutamate (GLU), aspartate (ASP), } \\
\text { serine, and glycine were determined by using high } \\
\text { performance liquid chromatography with electrochemical } \\
\text { detection }\end{array}$ \\
\hline Study design: & $\begin{array}{l}\text { Open-labeled, non-randomized, controlled experimental animal } \\
\text { study }\end{array}$ \\
\hline Outcome studied: & $\begin{array}{l}\text { Objective: To determine concentrations of excitatory and inhibitory } \\
\text { amino acids in CSF of a large number of dogs with idiopathic epilepsy } \\
\text { and to evaluate changes in CSF amino acid concentration with regard } \\
\text { to drug treatment and sex }\end{array}$ \\
\hline $\begin{array}{l}\text { Main findings: } \\
\text { (relevant to PICO question): }\end{array}$ & $\begin{array}{l}\text { CSF concentrations of GABA and GLU were significantly } \\
\text { lower in Labrador Retrievers with genetic epilepsythan in } \\
\text { control-group dogs or in non-Labrador Retrievers with } \\
\text { idiopathic epilepsy }\end{array}$ \\
\hline
\end{tabular}




\begin{tabular}{|c|c|}
\hline & $\begin{array}{l}\text { - CSF concentrations of GLU and ASP were significantly lower } \\
\text { when all dogs with epilepsy were compared with control- } \\
\text { group dogs }\end{array}$ \\
\hline Limitations: & $\begin{array}{l}\text { - Non-blinded and non-randomized } \\
\text { - Insufficient confidence level for diagnosing idiopathic } \\
\text { epilepsy }\end{array}$ \\
\hline
\end{tabular}

\begin{tabular}{|r|l|}
\hline \multicolumn{2}{|l|}{ Rusbridge (2004) } \\
\hline Sopulation: & Dogs with secondary syringomyelia and seizures \\
\hline Intervention details: & $\begin{array}{l}\text { A worldwide family tree of more than 5,500 CKCSs spanning a } \\
\text { maximum of } 24 \text { generations wasestablished by obtaining pedigree } \\
\text { information from } 120 \text { dogs diagnosed with secondary syringomyelia } \\
\text { secondary to occipital bone hypoplasia }\end{array}$ \\
\hline Study design: & Retrospective case series-pedigree analysis. \\
\hline Outcome studied: & $\begin{array}{l}\text { Objective: To identify the inheritance character of occipital bone } \\
\text { hypoplasia (Chiari type I malformation) in CavalierKing Charles } \\
\text { Spaniels. }\end{array}$ \\
\hline Main findings: & $\begin{array}{l}\text { Idiopathic epilepsy is more frequent in lines originating from whole- } \\
\text { color dogs. Selection for coat color is believed to have influenced the } \\
\text { development of both occipital hypoplasia with secondary SM and IE }\end{array}$ \\
\hline Limitations: & Not identified but retrospective case series-pedigree analysis study \\
\hline
\end{tabular}

\begin{tabular}{|c|c|}
\hline \\
\hline \multicolumn{2}{|c|}{\begin{tabular}{l|l} 
Population: & $\begin{array}{l}\text { Dogs with various neurological disorders, including idiopathic } \\
\text { epilepsy (insufficient level of confidence). }\end{array}$
\end{tabular}} \\
\hline Sample size: & 130 dogs, $n=130$ \\
\hline Intervention details: & $\begin{array}{l}2 \text { Investigation groups, } 1 \text { Control group. } \\
\text { - Investigation group 1: Dogs with different diseases of the } \\
\text { central nervous system } n=104 \\
\text { - Investigation group 2: Dogs with exercise induced } \\
\text { weakness. } n=6 \\
\text { - Control group: Neurologically healthy dogs } n=20\end{array}$ \\
\hline Study design: & $\begin{array}{l}\text { Open-labelled, non-randomised, controlled experimental animal } \\
\text { study }\end{array}$ \\
\hline Outcome studied: & $\begin{array}{l}\text { Objective: To determine reference values for pyruvate, lactate and } \\
\text { the pyruvate/lactate ratio in the blood and cerebrospinal fluid. }\end{array}$ \\
\hline $\begin{array}{l}\text { Main findings: } \\
\text { (relevant to PICO question): }\end{array}$ & $\begin{array}{l}\text { - Neurologically healthy dogs and patients with idiopathic } \\
\text { epilepsy displayed nearly the same values. } \\
\text { - The highest lactate concentrations were measured in dogs } \\
\text { with disc protrusion and inflammatory CNS diseases }\end{array}$ \\
\hline
\end{tabular}




\begin{tabular}{|l|l|}
\hline Limitations: & $\begin{array}{l}\text { - Non-blinded and non-randomized. } \\
\text { - Insufficient confidence level for diagnosing idiopathic } \\
\text { epilepsy }\end{array}$ \\
\hline
\end{tabular}

\begin{tabular}{|r|l|}
\hline \multicolumn{1}{|l|}{ Oberbauer (2003) } \\
\hline Sopulation: & Dogs with idiopathic epilepsy (insufficient level of confidence) \\
\hline Intervention details: & $\begin{array}{l}\text { Unclear } \\
\text { Genomic DNA from families of affected tervuren and sheepdogs was } \\
\text { screened with 100widely dispersed, polymorphic canine } \\
\text { microsatellite markers }\end{array}$ \\
\hline Study design: & Unclear \\
\hline Outcome studied: & $\begin{array}{l}\text { Objective: To investigate the genetics of epilepsy in the Belgian } \\
\text { tervuren and sheepdog }\end{array}$ \\
\hline Main findings: & $\begin{array}{l}\text { Although not significant (LOD scores <3.0), three genomic regions } \\
\text { have shown nominal linkage between markers and the epileptic } \\
\text { phenotype }\end{array}$ \\
\hline Limitations: & $\begin{array}{l}\text { - Only abstract was retrieved } \\
\text { Insufficient confidence level for diagnosing idiopathic } \\
\text { epilepsy }\end{array}$ \\
\hline
\end{tabular}

\begin{tabular}{|r|l|}
\hline \multicolumn{2}{|l|}{ Patterson (2003) } \\
\hline Sopulation: & Dogs with idiopathic epilepsy (Tier I-II) \\
\hline Intervention details: & 11 dogs, n=11 \\
\hline Study design: & $\begin{array}{l}\text { Medical record, seizure survey, and telephone interview information } \\
\text { was obtained for } 29 \text { Vizslas with idiopathic epilepsy (IE), 74 } \\
\text { unaffected siblings, and 41 parents to determine the common } \\
\text { clinical characteristics and most likely mode of inheritance. }\end{array}$ \\
\hline Outcome studied: & $\begin{array}{l}\text { Objective: To identify clinical characteristics and inheritance of } \\
\text { idiopathic epilepsy in Vizslas }\end{array}$ \\
\hline Main findings: & $\begin{array}{l}\text { Idiopathic epilepsy in Vizslas appears to be primarily a partial onset } \\
\text { seizure disorder that may be inherited as an autosomal recessive } \\
\text { trait }\end{array}$ \\
\hline Limitations: & $\begin{array}{l}\text { Overall high risk of bias related to the study design. Tier I confidence } \\
\text { level for diagnosing idiopathic epilepsy in some cases }\end{array}$ \\
\hline &
\end{tabular}

\begin{tabular}{|r|l|}
\hline \multicolumn{2}{|l|}{ Morita (2002) } \\
\hline Population: & Dogs with idiopathic epilepsy (Tier II) \\
\hline Sample size: & 11 dogs, $\mathrm{n}=11$ \\
\hline
\end{tabular}




\begin{tabular}{|c|c|}
\hline Intervention details: & $\begin{array}{l}\text { - Epileptic focus by electroencephalography (EEG) was } \\
\text { assessed by using an international 10-20 electrode system in } \\
11 \text { Shetland sheep dogs affected with familial idiopathic } \\
\text { epilepsy. } \\
\text { - Also, evaluation of the amino acids in the cerebrospinal fluid } \\
\text { (CSF) and a pathologic examination of the brains of } 8 \text { dogs } \\
\text { that died from status epilepticus were performed }\end{array}$ \\
\hline Study design: & $\begin{array}{l}\text { Open-labelled, non-randomised, uncontrolled experimental animal } \\
\text { study }\end{array}$ \\
\hline Outcome studied: & $\begin{array}{l}\text { Objective: To investigate the clinicopathologic findings of familial } \\
\text { frontal lobe epilepsy in Shetland sheepdogs }\end{array}$ \\
\hline $\begin{array}{l}\text { Main findings: } \\
\text { (relevant to PICO question): }\end{array}$ & $\begin{array}{l}\text { - The EEG analyses indicated spike and sharp wave complexes, } \\
\text { which were considered to be paroxysmal discharges. } \\
\text { - An increased value for glutamate or aspartate was found in } \\
\text { the CSF of some epileptic dogs. } \\
\text { - Histologically, acute neuronal necrosis and astrocytosis were } \\
\text { distributed predominantly }\end{array}$ \\
\hline Limitations: & $\begin{array}{l}\text { - Non-blinded, non-randomised and uncontrolled study } \\
\text { - Low study population }\end{array}$ \\
\hline
\end{tabular}

\begin{tabular}{|c|c|}
\hline \\
\hline \multicolumn{2}{|c|}{ Population: $\quad$ Dogs with idiopathic epilepsy (insufficient confidence level). } \\
\hline Sample size: & 50 dogs, $n=50$ \\
\hline Intervention details: & $\begin{array}{l}\text { Pedigree analysis was carried out on an open, non-preselected } \\
\text { population of } 4005 \text { dogs. Five different subpopulations with } 50 \\
\text { epileptic dogs from } 13 \text { generations were } \\
\text { Included }\end{array}$ \\
\hline Study design: & Pedigree Analysis \\
\hline Outcome studied: & $\begin{array}{l}\text { Objective: To investigate clinical and genetic icharacteristics of } \\
\text { idiopathic epilepsy in the Bernese mountain dog }\end{array}$ \\
\hline $\begin{array}{l}\text { Main findings: } \\
\text { (relevant to PICO question): }\end{array}$ & $\begin{array}{l}\text { - Idiopathic epilepsy has a polygenic, recessive mode of } \\
\text { inheritance in the Bernese mountain dog. } \\
\text { - A clear predisposition for males was also noted. The } \\
\text { majority ( } 62 \text { per cent) of the epileptic dogs had had their } \\
\text { first seizures at between one and three years of age }\end{array}$ \\
\hline Limitations: & $\begin{array}{l}\text { - Only abstract was retrieved. } \\
\text { - Insufficient confidence level for diagnosing idiopathic } \\
\text { epilepsy. }\end{array}$ \\
\hline
\end{tabular}

\begin{tabular}{|r|l|}
\hline Lengweiler (1999) \\
\hline Population: & Dogs with idiopathic epilepsy (insufficient level of confidence). \\
\hline Sample size: & 25 dogs, $n=25$ \\
\hline
\end{tabular}




\begin{tabular}{|c|c|}
\hline Intervention details: & $\begin{array}{l}\text { Questionnaire survey of the owners of } 25 \text { Golden Retrievers in } \\
\text { Switzerland [date not given], in which data were obtained on signs, } \\
\text { clinical history, feeding and housing }\end{array}$ \\
\hline Study design: & Questionnaire. Survey \\
\hline Outcome studied: & $\begin{array}{l}\text { Subjective: To investigate clinical, epidemiological and treatment } \\
\text { aspects of idiopathic epilepsy in } 25 \text { Golden Retrievers }\end{array}$ \\
\hline $\begin{array}{l}\text { Main findings: } \\
\text { (relevant to PICO question): }\end{array}$ & $\begin{array}{l}\text { - In half the dogs seizures first occurred between } 1 \text { and } 3 \\
\text { years of age and were mostly generalized. } \\
\text { - At the beginning of long-term therapy with phenobarbital } \\
\text { success was observed in two-thirds of dogs; after } 4 \text { years } \\
\text { symptoms worsened considerably in half the dogs. } \\
\text { Dogs responded well to therapy if treated as early as } \\
\text { possible. No better success rate in castrated dogs }\end{array}$ \\
\hline Limitations: & $\begin{array}{l}\text { - Risk of subjective assessment } \\
\text { - Insufficient confidence level for diagnosing idiopathic } \\
\text { epilepsy }\end{array}$ \\
\hline
\end{tabular}

\begin{tabular}{|r|l|}
\hline \multicolumn{2}{|l|}{ Holliday (1998) } \\
\hline Population: & Dogs with idiopathic epilepsy (Tier II) \\
\hline Sample size: & Unclear \\
\hline Intervention details: & $\begin{array}{l}\text { Inter-ictal electroencephalograms (EEGs) were performed in sedated } \\
\text { epileptic dogs }\end{array}$ \\
\hline Study design: & $\begin{array}{l}\text { Open-labeled, non-randomised, uncontrolled experimental animal } \\
\text { study }\end{array}$ \\
\hline Outcome studied: & $\begin{array}{l}\text { Objective: To investigate interictal paroxysmal discharges in the EEG } \\
\text { of epileptic dogs }\end{array}$ \\
\hline (relevant to PICO question): & $\begin{array}{l}\text { Using appropriate methods, focal paroxysmal discharges can } \\
\text { be detected and the hemisphere of origin and rostrocaudal } \\
\text { location of their sources identified. }\end{array}$ \\
\hline Limitations: & $\begin{array}{l}\text { Paroxysmal discharges that are presumably generalized can } \\
\text { be recorded from dogs with signalments suggesting } \\
\text { inherited/"idiopathic" epilepsy. }\end{array}$ \\
\hline $\begin{array}{l}\text { Only abstract was retrieved } \\
\text { - } \begin{array}{l}\text { Non-blinded and uncontrolled study } \\
\text { Compared to similar studies, sedation instead of general } \\
\text { anesthesia was used in the dogs of this study that might } \\
\text { have affected the EEG findings }\end{array}\end{array}$ \\
\hline
\end{tabular}

\begin{tabular}{|r|l|}
\hline Jaggy (1998a) \\
\hline Population: & Dogs with idiopathic epilepsy (insufficient confidence level) \\
\hline Sample size: & 792 dogs, $n=792$ \\
\hline
\end{tabular}




\begin{tabular}{|r|l|}
\hline Intervention details: & $\begin{array}{l}\text { Seven hundred and ninety-two pedigree certificates from a } \\
\text { population of healthy and epileptic dogs from 11 generations were } \\
\text { evaluated. Forty-four different families (giving a total of 55 epileptic } \\
\text { dogs) were included and analysed }\end{array}$ \\
\hline Study design: & Pedigree analysis \\
\hline Outcome studied: & $\begin{array}{l}\text { Subjective: To investigate genetic aspects of idiopathic epilepsy in } \\
\text { Labrador retrievers. }\end{array}$ \\
\hline Main findings: & $\begin{array}{l}\text { Results of pedigree analysis and from use of the binomial test } \\
\text { support the hypothesis of a polygenic, recessive mode of inheritance } \\
\text { in Labrador retrievers }\end{array}$ \\
\hline Limitations: & Insufficient confidence level for diagnosing idiopathic epilepsy \\
\hline
\end{tabular}

\begin{tabular}{|c|c|}
\hline \\
\hline \multicolumn{2}{|c|}{ Population: Dogs with idiopathic epilepsy (Tier II). } \\
\hline Sample size: & 37 dogs, $n=37$ \\
\hline Intervention details: & $\begin{array}{l}\text { Interictal electroencephalographic recordings of } 37 \text { anaesthetised } \\
\text { dogs were statistically analysed. }\end{array}$ \\
\hline Study design: & Retrospective case series study \\
\hline Outcome studied: & $\begin{array}{l}\text { Subjective: To investigate the clinical and electroencephalographic } \\
\text { findings in dogs }\end{array}$ \\
\hline $\begin{array}{l}\text { Main findings: } \\
\text { (relevant to PICO question): }\end{array}$ & $\begin{array}{l}\text { - Despite anaesthesia, electroencephalographic features were } \\
\text { consistent and unique in dogs with idiopathic epilepsy } \\
\text { - In this study males were predisposed to idiopathic epilepsy }\end{array}$ \\
\hline Limitations: & Retrospective case series \\
\hline
\end{tabular}

\begin{tabular}{|c|c|}
\hline 97) & \\
\hline Population: & Dogs with idiopathic epilepsy (insufficient confidence level). \\
\hline Sample size: & 29 dogs, $n=29$ \\
\hline Intervention details: & $\begin{array}{l}2 \text { Investigation groups, } 1 \text { Control group. } \\
\text { - Investigation group 1:_Drug-naive dogs with an initial } \\
\text { generalized seizure } n=13 \\
\text { - Investigation group 2: Drug-naive dogs with an initial } \\
\text { partial seizure } n=6 \\
\text { - Control group Clinically normal dogs } n=10 \\
\text { The CSF glutamate (GLU) and gamma-aminobutyric acid (GABA) } \\
\text { concentrations were estimated by use of HPLC with electrochemical } \\
\text { detection. }\end{array}$ \\
\hline Study design: & Open-labeled, non-randomised, controlled, experimental trial \\
\hline Outcome studied: & $\begin{array}{l}\text { Objectives: To investigate changes in CSF concentrations of } \\
\text { inhibitory and excitatory neurotransmitters in dogs with confirmed } \\
\text { idiopathic epilepsy, and to evaluate them with regard to the clinical }\end{array}$ \\
\hline
\end{tabular}




\begin{tabular}{|r|c|}
\hline & characteristics of the sample population and of the seizures. \\
\hline $\begin{array}{r}\text { Main findings: } \\
\text { (relevant to PICO question): }\end{array}$ & $\begin{array}{l}\text { Altered GABA and GLU values in CSF might be indicative of a state of } \\
\text { chronic over excitation in the brain of dogs with idiopathic epilepsy }\end{array}$ \\
\hline Limitations: & $\begin{array}{l}\text { - Non-randomised, non-blinded. } \\
\text { Insufficient confidence level for diagnosing idiopathic } \\
\text { epilepsy. }\end{array}$ \\
\hline
\end{tabular}

\begin{tabular}{|c|c|}
\hline \multicolumn{2}{|l|}{ Hall (1996) } \\
\hline Population: & $\begin{array}{l}\text { Dogs with idiopathic epilepsy(insufficient level of confidence) and } \\
\text { healthy animals }\end{array}$ \\
\hline Sample size: & Unclear \\
\hline Intervention details: & $\begin{array}{l}\text { Pedigrees of } 15 \text { litters which included animals diagnosed as epileptic } \\
\text { ('fitters') were compared with those of } 34 \text { contemporary, normal } \\
\text { animals }\end{array}$ \\
\hline Study design: & Prospective case series \\
\hline Outcome studied: & $\begin{array}{l}\text { Objective: To investigate a genetic counselling programme for } \\
\text { Keeshonds }\end{array}$ \\
\hline $\begin{array}{l}\text { Main findings: } \\
\text { (relevant to PICO question): }\end{array}$ & $\begin{array}{l}\text { The predisposition of Keeshonds (Dutch barge dogs) to idiopathic } \\
\text { epilepsy appears to be determined by a single autosomal recessive } \\
\text { gene }\end{array}$ \\
\hline Limitations: & $\begin{array}{l}\text { - Only abstract was retrieved. } \\
\text { - Insufficient confidence level for diagnosing idiopathic } \\
\text { epilepsy. }\end{array}$ \\
\hline
\end{tabular}

\begin{tabular}{|c|l|}
\hline \multicolumn{2}{|l|}{ Srenk (1996) } \\
\hline Sopulation: & $\begin{array}{l}\text { Dogs with idiopathic epilepsy (Tier II), exercise induced weakness } \\
\text { and healthy dogs. }\end{array}$ \\
\hline Intervention details: & 15 dogs, n=15 \\
\hline & $\begin{array}{l}2 \text { Investigation groups, 1 Control group. } \\
\text { Electroencephalograms (EEGs) were performed. Constant and } \\
\text { similar values of amplitude and frequency were found under } \\
\text { medetomidine/propofol anaesthesia. } \\
\bullet \quad \text { Investigation group 1: Dogs with idiopathic epilepsy n=5 } \\
\text { Study design: Investigation group 2: Dogs with exercise induced }\end{array}$ \\
\hline Outcome studied: & $\begin{array}{l}\text { Open-labeled, non-randomised, controlled experimental animal } \\
\text { study. }\end{array}$ \\
\hline & $\begin{array}{l}\text { Objective: } \\
\text { To investigate interictal electroencephalographic findings in a family } \\
\text { of Golden Retrievers with idiopathic epilepsy. }\end{array}$ \\
\hline &
\end{tabular}




\begin{tabular}{|r|l|}
\hline Main findings: & - $\begin{array}{l}\text { Despite deep anaesthesia, the EEG abnormalities were } \\
\text { (relevant to PICO question): }\end{array}$ \\
& $\begin{array}{l}\text { consistent and extremely important for the confirmation of } \\
\text { idiopathic epilepsy in the dog. }\end{array}$ \\
\hline Limitations: & $\begin{array}{l}\text { EEG combined with pedigree analysis may be very helpful in } \\
\text { risk assessment of IE in the dog }\end{array}$ \\
& $\begin{array}{l}\text { - Non-blinded and non-randomised } \\
\text { - Low study population }\end{array}$ \\
\hline
\end{tabular}

\begin{tabular}{|r|l|}
\hline \multicolumn{2}{|l}{ Podell (1995) } \\
\hline Population: & Dogs with seizures. \\
\hline Sample size: & 50 dogs, $\mathrm{n}=50$ \\
\hline Intervention details: & $\begin{array}{l}\text { Fifty dogs were classified on the basis of antemortem and } \\
\text { postmortem test results and history. }\end{array}$ \\
\hline Outcome studied: & $\begin{array}{l}\text { Objective: To investigate the seizure classification in dogs from a non } \\
\text { referral-based population. }\end{array}$ \\
\hline Main findings: & $\begin{array}{l}\text { A diagnosis of idiopathic epilepsy was more probable when the dog } \\
\text { was between } 1 \text { and } 5 \text { years of age at the first seizure, when the dog } \\
\text { was a large breed (>15 kg), when the seizure occurred between } 8 \text { am } \\
\text { and midnight, or when the interval between the first and second } \\
\text { seizure was long ( }>4 \text { weeks). }\end{array}$ \\
\hline Limitations: & Retrospective case series. \\
\hline &
\end{tabular}

\begin{tabular}{|c|c|}
\hline \multicolumn{2}{|l|}{ Koutinas (1994) } \\
\hline Population: & Dogs with idiopathic epilepsy (Tier I level of confidence). \\
\hline Sample size: & 14 dogs, $n=14$ \\
\hline Intervention details: & Clinical and clinicopathological description of 14 epileptic dogs. \\
\hline Study design: & Retrospective case series \\
\hline Outcome studied: & $\begin{array}{l}\text { Objective: To investigate the clinical and clinicopathological findings } \\
\text { as well as response to treatment in epileptic dogs. }\end{array}$ \\
\hline $\begin{array}{l}\text { Main findings: } \\
\text { (relevant to PICO question): }\end{array}$ & $\begin{array}{l}\text { - Between seizures, neurological and funduscopic } \\
\text { examinations were normal, and no important biochemical, } \\
\text { haematological or cerebrospinal fluid abnormalities were } \\
\text { observed } \\
\text { - Of } 8 \text { dogs treated with phenobarbital, seizures were } \\
\text { controlled completely in } 6 \text { and partially in } 2\end{array}$ \\
\hline Limitations: & $\begin{array}{l}\text { - Retrospective case series } \\
\text { - Low study population } \\
\text { - Tier I level of confidence for diagnosing idiopathic epilepsy }\end{array}$ \\
\hline
\end{tabular}




\begin{tabular}{|c|c|}
\hline \multicolumn{2}{|l|}{ Srenk (1994) } \\
\hline Population: & Dogs with idiopathic epilepsy (insufficient level of confidence). \\
\hline Sample size: & 336 dogs, $n=336$ \\
\hline Intervention details: & $\begin{array}{l}\text { Analysis of the pedigrees of } 336 \text { Swiss-bred Golden Retrievers over } \\
\text { five generations. }\end{array}$ \\
\hline Study design: & Retrospective case series study \\
\hline Outcome studied: & $\begin{array}{l}\text { Objective: To investigate the genetic background for idiopathic } \\
\text { epilepsy in Golden Retrievers. }\end{array}$ \\
\hline $\begin{array}{l}\text { Main findings: } \\
\text { (relevant to PICO question): }\end{array}$ & $\begin{array}{l}\text { - Males were particularly at risk. } \\
\text { - There was evidence of an autosomal multifactorial recessive } \\
\text { mode of inheritance }\end{array}$ \\
\hline Limitations: & $\begin{array}{l}\text { - Retrospective case series } \\
\text { - Insufficient confidence level for diagnosing idiopathic } \\
\text { epilepsy }\end{array}$ \\
\hline
\end{tabular}

The level of confidence for diagnosing idiopathic epilepsy (Tier I-III) used in this knowledge summary was based on the international veterinary epilepsy task force (IVETF) consensus statement on the diagnosis of idiopathic epilepsy (De Risio, L. et al. 2015). Any paper that included dogs with idiopathic epilepsy for which diagnostic investigations were below this Tier level of evidence or unclear was considered to provide insufficient level of confidence for diagnosing idiopathic epilepsy. Tier I was listed in the limitations of the papers as this could indicate that a few dogs might have suffered from structured epilepsy and as a result have not responded adequately or at all to the treatment. In addition, the terminology used was based on the IVETF consensus statement on the definition, classification and terminology of seizures in companion animals (Berendt, M. et al. 2015).

\section{Appraisal, application and reflection}

Idiopathic epilepsy is a diagnosis of exclusion. The studies included in this summary supportthe fact that a thorough investigation of history and dog's signalment are vital "starting points" for excluding other potential underlying causes of seizures. In all the studies the vast majority of dogs with confirmed or, at least, presumptive idiopathic epilepsy had an age onset less than 6-7 years. Armaşu et al. (2014) found that $89 \%$ of dogs with idiopathic epilepsy had an age of seizure onset $<6$ years. Similarly, Smith et al. (2008) reported that only $2.2 \%$ of dogs $<6$ years old with unremarkable inter-ictal neurological examination had significant lesion (identifiable on MRI), compared to $26.7 \%$ of dogs $>6$ years old.Pákozdy et al. (2008) provided a more limited scale for the age of seizures onset ( $<5$ years). Podell et al. (1995) reported that the diagnosis of idiopathic epilepsy was more probable when the dog experienced the first seizure(s) between 1 and 5 years of age and was a large breed (>15 kg). Viitmaa et al. (2013), Kloene et al. (2008), Casal et al. (2006) and Patterson et al. (2005) found that the median age of seizure onset in their study population was 3 years. De Risio et al. (2015) combined and analyzed the data from Pákozdy et al. (2008) and Armaşu et al. (2014) and found that there was a significant association between age of onset and cause of epilepsy for dogs under 6 years of age at epileptic seizure onset (Chi-squared $=5.136, n=431, p=0.023$ ) when the cut-off was set at 6 months. Dogs aged between 6 months and 6 years were significantly more likely to be affected by idiopathic than structural epilepsy in comparison to the dogs aged beyond this range.

Various breeds have been considered to be prone to idiopathic epilepsy. Multiple genes and recessive modes of inheritance have been investigated. Seppälä et al. (2012), Ekenstedt, K. et al. (2011), Kloene, J. et al. (2008), 
Pákozdy et al. (2008), Licht et al. (2007), Casal, M. et al. (2006), Patterson et al. (2005), Patterson et al. (2003), Kathmann et al. (1999), Jaggy et al. (1998a) and Hall et al. (1996) reported various breeds. Also, the consensus statement by Hülsmeyer et al. (2015), reviewed all the current evidence available for breeds that have been identified as being predisposed to idiopathic epilepsy with a proven or suspected genetic background.

Specifically, breeds include German shepherds, Australian Shepherds, Belgian Shepherds, Bernese mountain dogs, Beagles, Border Collies, Border Terriers, Cavalier King Charles Spaniels, Dachshunds, Dalmatians, English Springer Spaniels, Finnish Spitz, Golden Retrievers, Hungarian Vizslas, Lagotto Romagnolo, Labrador Retrievers, Irish Wolfhounds, Italian Spinone, Petit Basset Griffon Vendeen, Shetland Sheepdogs, Standard Poodles and Keeshonds. Jokinen et al. (2007) reported juvenile epilepsy in Lagotto Romagnolo with mainly focal seizures and seizure onset of 5 to 9 weeks. Rusbridge et al. (2004) reported that idiopathic epilepsy in Cavalier King Charles spaniels is more frequent in lines originating from whole-colour dogs. The latter characteristic was also considered to influence the development of occipital hypoplasia.

Distribution of epilepsy has been considered to be affected by gender. Most reports suggest males have an increased likelihood to develop seizures compared to females. Viitmaa et al. (2013), Jaggy and Bernadini (2008), Pákozdy et al. (2008) and Casal et al. (2006) found that males were predisposed to idiopathic epilepsy. Freds $\varnothing$, N. et al. (2014) reported that neutered male dogs with idiopathic epilepsy had a significant shorter survival (median: 38.5 months) compared to intact male dogs (median: 71 months). Van Meervenne et al. (2014) also reported and that there was an over-representation of male dogs with idiopathic epilepsy but no conclusions could be drawn as far as the effect of sterilisation status in seizures is concerned. In a retrospective case series study by Van Meervenne et al. (2014), it was suggested an association between oestrus and seizures onset in intact female dogs with presumptive idiopathic epilepsy. However, Pákozdy et al. (2008) found no correlation of seizures with oestrus as well as stress or excitement. In addition, the relation between lunar cycle and seizures has been investigated by Browand-Stainback et al. (2011) and Pákozdy et al. (2008) who showed no relationship between the two.

Apart from the signalment and history, the cornerstone for diagnosing idiopathic epilepsy is a normal interictal neurological examination. Prior to the neurological examination, though, a general clinical examination should be performed to detect possible signs that could be related to or even be confused with seizures. In all the studies the dogs with confirmed or presumptive idiopathic epilepsy had normal inter-ictal neurological status (only a few dogs had neurological signs but these were considered as postictal). Indeed, Armasu et al. (2007) reported that there are further risk factors, besides signalment, that increase or decrease the risk of intracranial pathology or provide one with a diagnosis of idiopathic epilepsy. Precisely, the seizure severity (e.g. cluster seizures) and abnormal neurological examination findings (which was considered one of the most important) were highly associated withstructural epilepsy. The same authors reported that $84 \%$ of dogs with idiopathic epilepsy had a normal neurological examination. Smith et al. (2008) and Pákozdy et al. (2008) also supported that unremarkable inter-ictal neurological findings in combination with the age of seizure onset are important factors for diagnosing idiopathic epilepsy. Specifically, Pákozdy et al. (2008) reported that status epilepticus, cluster seizures, partial seizures, vocalisation during seizure and impaired neurological status were more readily seen with structural epilepsy. Ghormie et al. (2015) found that in 99 dogs $\geq 5$ years of age at seizure onset, an abnormal neurologic examination had $74 \%$ sensitivity and $62 \%$ specificity to predict structural epilepsy. Armaşu et al. (2014) found that dogs with neurological abnormalities interictally were 16.5 and 12.5 times more likely to have an asymmetrical structural cerebral lesion and a symmetrical structural cerebral lesion, respectively, rather than idiopathic epilepsy.

Magnetic resonance imaging (MRI) of the brain, clinicopathological tests, i.e. haematological, biochemistry 
profile and urinalysis as well as cerebrospinal fluid (CSF) analysis can be considered an important part in the diagnostic investigation of idiopathic epilepsy. De Risio et al. (2015) suggested that clinicians should perform brain MRI and CSF analysis, after exclusion of reactive seizures, in dogs with age at epileptic seizure onset $<6$ months or $>6$ years, inter-ictal neurological abnormalities as a result of intracranial lesion, status epilepticus or cluster seizure at epileptic seizure onset, or a previous presumptive diagnosis of IE and in refractory cases. The findings from these results are expected to be unremarkable and non-indicative of any known underlying cause of seizures.

In the plasma and CSF, in particular, various studies have been performed to reveal potential biomarkers that would help to identify epilepsy in dogs, either in earlier or later stages of the disease. Bartels et al. (2014) showed that chemokines (e.g. CCL19) were increased in dogs with idiopathic epileptic compared to healthy individuals; but compared to dogs with other neuro-inflammatory diseases, chemokines were markedly decreased. Hasegawa et al. (2014) showed that metabolites including glutamic acid and ascorbic acid in CSF might be useful for the diagnosis of canine epilepsy. Merbl et al. (2014) found higher CSF concetrations of tumour necrosis factor- $\alpha$ (TNF- $\alpha$ ) and interleukin-6 (IL-6) in dogs with naturally occurring seizures compared to a control group of healthy dogs. Wessmann et al. (2010) found epithelial cells in $6.5 \%$ of dogs of the study population affected by idiopathic epilepsy, although it was considered as a non-specific incidental finding. Goncalves et al. (2010) reported that seizures could initially result in a mild increase oftotal nucleated cell count; thus, this fact should be considered when taking CSF straight after a seizure (false positive elevation). Podell, M. et al. (1997) reported that altered gamma-aminobutyric acid and glutamate values in CSF might be indicative of a state of chronic overexcitation in the brain of dogs with idiopathic epilepsy. Similarly, Ellenberger et al. (2004), reported that CSF concentrations of gamma-aminobutyric acid and glutamate were significantly lower in Labrador Retrievers with genetic epilepsy compared to control group dogs or in nonLabrador Retrievers with idiopathic epilepsy; the same study showed that CSF concentration of aspartate was significantly lower in all the epileptic dogs. Creevy et al. (2013) and Gesell et al. (2013) found that glutamate and endocannabinoids anandamide (AEA) concentrations, respectively, were higher in CSF of dogs with idiopathic epilepsy compared to a control group of healthy dogs. Calvo (2012) measured the C-reactive protein in the blood of dogs with idiopathic epilepsy and, contrary to dogs suffering from other causes of seizures as well as healthy dogs, detected increased concentrations within 24 hours but a decline after that period. Further CSF and/or plasma indicators that were investigated failed to contribute towards the diagnosis of idiopathic epilepsy. Specifically, Weber et al. (2012), Fuente et al. (2012), Fujiwara et al. (2008) and Lobert, V. et al. (2003) showed that CSF glucose level/glucose ratio, D-dimers, glial fibrillary acidic protein autoantibodies and pyruvate/lactate levels respectively were not useful for supporting the diagnoses of idiopathic epilepsy. In all, based on these results, researchers succeeded or failed to establish certain plasma and/or CSF biomarkers associated with seizures in epileptic dogs. However, there is still research that could be performed in the future, either for the above or new biomarkers for epilepsy.

Electroencephalogram (EEG) is regularly used as one of the diagnostic procedures in humans and its utility in dogs has been assessed in a few studies. Jaggy et al. (1998b) and Srenk et al. (1996) reported that, despite anaesthesia, interictal EEG features were consistent and unique in dogs with idiopathic epilepsy. Holliday and Williams (1998) reported that interictal EEG might be useful diagnostic technique in dogs with idiopathic epilepsy. Viitmaa et al. (2014)supported the use of fluoro-d-glucose positron emission tomography (FDG-PET) and to less extend, EEG in epileptic dogs as diagnostic tool.However, Akos et al. (2012) revealed that interictal EEG rarely showed epileptic discharges and therefore the diagnostic value of the EEG in the diagnosis of epilepsy appeared to be low. Brauer et al. (2012) found that interictal EEG was not a useful diagnostic method because it could detect epileptic activity in less than one third of all seizuring dogs (including symptomatic 
epilepsy) of the study population. All in all, there are quite a few challenges of using EEG routinely in animals and further work need to be performed.

In conclusion, diagnosis should be based on history, signalment (age of onset ( $>6$ months and $<6$ years), breed, sex), normal interictal neurological examination, seizure type, unremarkable complete blood count, biochemistry profile and urinalysis in the first instance. This can be supported by excluding structural lesions with advanced brain imaging techniques (i.e. MRI) and an unremarkable CSF analysis and cytology. EEG for identification of the characteristic patterns of epileptic seizures is highly recommended as a confirmation of the diagnosis.Based on the recent consensus statement by De Risio et al. (2015), all these diagnostic features and tests were categorized based on their value in criteria for the diagnosis of idiopathic epilepsy are described in a three-tier system. Precisely, Tier I is based on signalment, history, general and neurological examination as well as minimum data base blood tests and urinalysis. Tier II is based on tier I, plus unremarkable fasting plus post-prandial bile acids as well as brain MRI and CSF analysis. Tier III is based on tier I and II, plus identification of electroencephalographic abnormalities characteristic for seizure disorders.

Implications for the future: Advance diagnostic procedures, such as MRI and EEG willbecome more widely available in order to improve the quality of diagnosis of canine epilepsy. Recently, the consensus statements by Rusbridge et al. (2015) and Matiasek et al. (2015) recommended specific MRI and diagnostic pathology protocol, respectively, for investigating idiopathic epilepsy. Lastly, further studies with a high quality design (i.e. blinded randomised controlled studies), low overall risk of bias and greater number of dogs investigating established or new diagnostic methods (e.g. CSF or serum biomarkers) for idiopathic epilepsy are needed because the current evidence in veterinary medicine is relatively weak.

Limitation of the summary: The main limitation of this summary is that we could not obtain full access to a few papers included in the summary of evidence. These included: Hasegawa, T. et al. (2014), BrowandStainback, L. et al. (2011), Ekenstedt, K. et al. (2011), Oberbauer, A. et al. (2003), Kathmann, I. et al. (1999), Holliday, T. and Williams, D. (1998) and Hall, S. et al. (1996).

\section{Methodology Section}

\begin{tabular}{|c|c|}
\hline \multicolumn{2}{|l|}{ Search Strategy } \\
\hline $\begin{array}{r}\text { Databases searched and dates } \\
\text { covered: }\end{array}$ & $\begin{array}{l}\text { PubMed and CAB Abstracts } 1973 \text { to } 2015 \text { combined search on OVID } \\
\text { platform }\end{array}$ \\
\hline Search terms: & $\begin{array}{l}\text { (dog or dogs or puppy or puppies or canis or canine) AND (idiopath*) } \\
\text { AND (epilep* or seizur* or convuls*) AND (diagnos* or identif* or } \\
\text { assess* or test* or exam* or history or compaint* or symptom* or } \\
\text { risk* or aetiolog* or etiolog*) }\end{array}$ \\
\hline Dates searches performed: & $23 / 11 / 15$ \\
\hline
\end{tabular}


Exclusion / Inclusion Criteria

Exclusion: Summary updates, Non-systematic reviews*

Inclusion: Studies evaluating or reporting the diagnosis of canine idiopathic epilepsy

*There was a non-systematic review Van Meervenne, et al. (2014a) that was included because it made important conclusions and valuable up-to-date points for our summary. This paper was not included in the table but in the text.The same applies for the IVETF consensus statements by Berendt et al. (2015), De Risio et al. (2015), Hülsmeyer et al. (2015), Matiasek et al. (2015) and Rusbridge et al. (2015)

\begin{tabular}{|l|c|c|c|c|c|}
\hline \multicolumn{2}{|l|}{ Search Outcome } \\
\hline Database & $\begin{array}{c}\text { Number } \\
\text { of } \\
\text { results }\end{array}$ & Excluded - study design & $\begin{array}{c}\text { Excluded - did } \\
\text { not answer PICO } \\
\text { question }\end{array}$ & $\begin{array}{c}\text { Excluded - } \\
\text { duplicates }\end{array}$ & $\begin{array}{c}\text { Total } \\
\text { relevant } \\
\text { papers }\end{array}$ \\
\hline $\begin{array}{l}\text { PubMed and } \\
\text { CAB }\end{array}$ & 260 & 28 & 22 & 162 & 48 \\
Abstracts & 28 & & & 48 \\
\hline
\end{tabular}

\section{REFERENCES}

1. Armaşu, M., et al (2014) An exploratory study using a statistical approach as a platform for clinical reasoning in canine epilepsy The Veterinary Journal, 202(2), pp.292-296 http://dx.doi.org/10.1016/j.tvjl.2014.08.008

2. Akos, P. et al (2012) Electroencephalographic examination of epileptic dogs under propofol restraint. Acta Veterinaria Hungarica, 60(3), pp. 309-324 http://dx.doi.org/10.1556/AVet.2012.026

3. Bartels, J. et al. (2014). MIP-3beta/CCL19 is associated with the intrathecal invasion of mononuclear cells in neuroinflammatory and non-neuroinflammatory CNS diseases in dogs. BMC veterinary research, 10:157 http://dx.doi.org/10.1186/1746-6148-10-157

4. Berendt, M., et al. (2015) International veterinary epilepsy task force consensus report on epilepsy definition, classification and terminology in companion animals. BMC veterinary research, 11:182 http://dx.doi.org/10.1186/s12917-015-0461-2

5. Brauer, C., et al. (2012) Electroencephalographic recordings in dogs suffering from idiopathic and symptomatic epilepsy: diagnostic value of interictal short time EEG protocols supplemented by two activation techniques. The Veterinary Journal, 193(1), pp. 185-192 http://dx.doi.org/10.1016/i.tvil.2011.10.006

6. Browand-Stainback, L., Levesque, D. and McBee, M. (2011) Canine and feline epileptic seizures and the lunar cycle: 2,507 seizures (2000-2008). Journal of the American Animal Hospital Association 47(5), pp.324-328 http://dx.doi.org/10.5326/JAAHA-MS-5591 
7. Calvo, D. B. (2012) Study of C-reactive protein concentrations in serum and cerebrospinal fluid in dogs with idiopathic epilepsy. Masters dissertation, Faculdade de Medicina Veterinaria e Zootecnia, Universidade de Sao Paulo,

8. Casal, M. L., et al (2006) Epilepsy in Irish Wolfhounds. Journal of Veterinary Internal Medicine, 20(1), pp.131-135 http://dx.doi.org/10.1111/j.1939-1676.2006.tb02832.x

9. Creevy, K. E., et al (2013) Comparison of concentrations of gamma -aminobutyric acid and glutamate in cerebrospinal fluid of dogs with idiopathic epilepsy with and without seizure-related magnetic resonance imaging hyperintense areas in the limbic system. American Journal of Veterinary Research, 74(8), pp 1118-1125 http://dx.doi.org/10.2460/ajvr.74.8.1118

10. De Risio, L. et al. (2015) International veterinary epilepsy task force consensus proposal: diagnostic approach to epilepsy in dogs. BMC veterinary research, 11:148 http://dx.doi.org/10.1186/s12917-015$\underline{0462-1}$

11. Ekenstedt, K. J., et al (2011) Candidate genes for idiopathic epilepsy in four dog breeds. BMC Genetics, 12:38 http://dx.doi.org/10.1186/1471-2156-12-38

12. Ellenberger, C., et al 2004) Inhibitory and excitatory neurotransmitters in the cerebrospinal fluid of epileptic dogs. American Journal of Veterinary Research, 65(8). pp.1108-1113 http://dx.doi.org/10.2460/ajvr.2004.65.1108

13. Freds $\varnothing$, N., et al (2014) Risk factors for survival in a university hospital population of dogs with epilepsy. Journal of Veterinary Internal Medicine, 28(6), pp.1782-1788 http://dx.doi.org/10.1111/jvim.12443

14. de la Fuente, C.et al. (2012) Fibrinolytic activity in cerebrospinal fluid of dogs with different neurological disorders. Journal of Veterinary Internal Medicine,, 26(6), pp. 1365-1373 http://dx.doi.org/10.1111/j.1939-1676.2012.00991.x

15. Fujiwara, K., et al (2008) Autoantibodies against glial fibrillary acidic protein in canine sera. Veterinary Record, 162(18), pp. 592-593 http://dx.doi.org/10.1136/vr.162.18.592

16. Gesell, F. K., et al (2013) Alterations of endocannabinoids in cerebrospinal fluid of dogs with epileptic seizure disorder. BMC veterinary research, 9:262 http://dx.doi.org/10.1186/1746-6148-9-262

17. Ghormie, T.M., Feldman, D.G. and Cook, J.R. (2015) Epilepsy in dogs five years of age and older: 99 cases (2006-2011). Journal of the American Veterinary Medical Association.,246(4), pp. 447-450 http://dx.doi.org/10.2460/iavma.246.4.447

18. Goncalves, R., et al (2010) Effect of seizures on cerebrospinal fluid analysis in dogs with idiopathic epilepsy. Veterinary Record,166(16), pp. 497-498 http://dx.doi.org/10.1136/vr.b4812

19. Hall, S. J. G. and Wallace, M. E. (1996) Canine epilepsy: a genetic counselling programme for Keeshonds. Veterinary Record, 138(15), pp.358-360 http://dx.doi.org/10.1136/vr.138.15.358

20. Hülsmeyer, V. I. et al. (2015) International Veterinary Epilepsy Task Force's current understanding of idiopathic epilepsy of genetic or suspected genetic origin in purebred dogs. BMC veterinary research, 11:175 http://dx.doi.org/10.1186/s12917-015-0463-0

21. Hasegawa, T., et al (2014) Gas chromatography-mass spectrometry-based metabolic profiling of cerebrospinal fluid from epileptic dogs. The Journal of veterinary medical science 76(4), pp.517-522. http://dx.doi.org/10.1292/jvms.13-0520

22. Holliday, T.A. and Williams, D.C. (1998) Interictal paroxysmal discharges in the electroencephalograms of epileptic dogs. Clinical Techniques in Small Animal Practice,13(3), pp.132-143 http://dx.doi.org/10.1016/S1096-2867(98)80034-0

23. Jaggy, A., et al (1998a) Genetic aspects of idiopathic epilepsy in Labrador retrievers. Journal of Small Animal Practice 39(6), pp.275-280 http://dx.doi.org/10.1111/j.1748-5827.1998.tb03650.x

24. Jaggy, A. and Bernardini, M. (1998b) Idiopathic epilepsy in 125 dogs: a long-term study. Clinical and electroencephalographic findings. Journal of Small Animal Practice., 39(1), pp.23-29 http://dx.doi.org/10.1111/j.1748-5827.1998.tb03665.x

25. Jokinen, T. S., et al (2007) Benign familial juvenile epilepsy in Lagotto Romagnolo dogs. Journal of Veterinary Internal Medicine 21(3), pp. 464-471 http://dx.doi.org/10.1111/j.1939-

1676.2007.tb02991.x 
26. Kathmann, I. et al (1999) Clinical and genetic investigations of idiopathic epilepsy in the Bernese mountain dog. Journal of Small Animal Practice. 40(7), pp.319-325 http://dx.doi.org/10.1111/j.17485827.1999.tb03089.x

27. Kloene, J., et al (2008) Clinical investigations of seizures in Border Terriers. Kleintierpraxis, 53(1), pp. 512

28. Koutinas, A. F., Polizopoulou, Z. S. and Kontos, V. I. (1994) Clinical and clinicopathological evaluation in 14 dogs with presumed idiopathic epilepsy. Bulletin of the Hellenic Veterinary Medical Society 45(2), pp.141-149

29. Lengweiler, C. and Jaggy, A. (1999) Clinical, epidemiological and therapeutic aspects of idiopathic epilepsy in 25 Golden Retrievers: results of a long-term study. Schweizer Archiv fur Tierheilkunde, 141(5), pp.231-238

30. Licht, B. G., et al (2007) Clinical characteristics and mode of inheritance of familial focal seizures in Standard Poodles. Journal of the American Veterinary Medical Association, 231(10), pp. 1520-1528 http://dx.doi.org/10.2460/iavma.231.10.1520

31. Lobert, V., Mischke, R. and Tipold, A. (2003) Lactate and pyruvate levels in blood and cerebrospinal fluid. Kleintierpraxis, 48(12), pp. 735-743

32. Matiasek, K. et al. (2015) International veterinary epilepsy task force recommendations for systematic sampling and processing of brains from epileptic dogs and cats. BMC Veterinary Research, 11:216 http://dx.doi.org/10.1186/s12917-015-0467-9

33. Merbl, Y.,et al (2014) Tumor necrosis factor- $\alpha$ and interleukin- 6 concentrations in cerebrospinal fluid of dogs after seizures. Journal of Veterinary Internal Medicine 28(6), pp.1775-1781 http://dx.doi.org/10.1111/jvim.12462

34. Morita, T., et al (2002) Cliniconeuropathologic findings of familial frontal lobe epilepsy in Shetland sheepdogs. Canadian Journal of Veterinary Research, 66(1), pp. 35-41

35. Oberbauer, A.M., et al (2003) The genetics of epilepsy in the Belgian tervuren and sheepdog. Journal of Heredity, 94(1), pp.57-63 http://dx.doi.org/10.1093/ihered/esg010

36. Pákozdy, A., et al (2006) Seizures in boxer - a retrospective study (1999-2005). Wiener Tierarztliche Monatsschrift, 93, pp.270-276

37. Pákozdy, A., et al. (2008) Retrospective clinical comparison of idiopathic versus symptomatic epilepsy in 240 dogs with seizures. Acta Veterinaria Hungarica 56(4), pp.471-483 http://dx.doi.org/10.1556/AVet.56.2008.4.5

38. Patterson, E. E., et al (2005) Clinical description and mode of inheritance of idiopathic epilepsy in English Springer Spaniels. Journal of the American Veterinary Medical Association, 226(1), pp. 54-58 http://dx.doi.org/10.2460/javma.2005.226.54

39. Patterson, E.E., et al (2003) Clinical characteristics and inheritance of idiopathic epilepsy in Vizslas. Journal of Veterinary Internal Medicine 17(3), pp.319-325 http://dx.doi.org/10.1111/i.19391676.2003.tb02455.x

40. Podell, M. and Hadjiconstantinou, M. (1997) Cerebrospinal fluid gamma-aminobutyric acid and glutamate values in dogs with epilepsy. American Journal of Veterinary Research, 58(5), pp. 451-456

41. Podell, M., Fenner, W. R., and Powers, J. D. (1995) Seizure classification in dogs from a nonreferralbased population. Journal of the American Veterinary Medical Association 206(11), pp.1721-1728

42. Rusbridge, C., and Knowler, S.P. (2004) Inheritance of occipital bone hypoplasia (Chiari type I malformation) in Cavalier King Charles Spaniels. Journal of Veterinary Internal Medicine 18(5), pp.673678 http://dx.doi.org/10.1111/i.1939-1676.2004.tb02605.x

43. Rusbridge, C., et al. (2015) International Veterinary Epilepsy Task Force recommendations for a veterinary epilepsy-specific MRI protocol. BMC veterinary research, 11:194 http://dx.doi.org/10.1186/s12917-015-0466-x

44. Seppälä, E.H., et al (2012) Identification of a novel idiopathic epilepsy locus in Belgian Shepherd dogs. PLoS One, 7(3): e33549 http://dx.doi.org/10.1371/journal.pone.0033549

45. Smith, P.M., Talbot, C.E. and Jeffery, N.D. (2008) Findings on low-field cranial MR images in epileptic dogs that lack interictal neurological deficits. The Veterinary journal, 176(3), pp. 320-325

http://dx.doi.org/10.1016/j.tvjl.2007.03.003 
46. Srenk, P., et al. (1994) Genetic background for idiopathic epilepsy in Golden Retrievers. Tierarztliche Praxis, 22(6), pp.574-578

47. Srenk, P. and Jaggy, A. (1996) Interictal electroencephalographic findings in a family of Golden Retrievers with idiopathic epilepsy. Journal of Small Animal Practice 37(7), pp.317-321 http://dx.doi.org/10.1111/j.1748-5827.1996.tb02398.x

48. Van Meervenne, S.A E. et al. (2015) Association between Estrus and Onset of Seizures in Dogs with Idiopathic Epilepsy. Journal of Veterinary Internal Medicine 29(1) pp 251-263 http://dx.doi.org/10.1111/jvim.12505

49. Van Meervenne, S. A. E. et al (2014) The influence of sex hormones on seizures in dogs and humans. The Veterinary Journal, 201(1), pp.15-20 http://dx.doi.org/10.1016/j.tvjl.2014.05.008

50. Viitmaa, R., et al . (2006) Magnetic resonance imaging findings in Finnish spitz dogs with focal epilepsy. Journal of Veterinary Internal Medicine 20(2), pp. 305-310 http://dx.doi.org/10.1111/j.19391676.2006.tb02861.x

51. Viitmaa, R., et al (2013). Phenotype, inheritance characteristics, and risk factors for idiopathic epilepsy in Finnish Spitz dogs. Journal of the American Veterinary Medical Association, 243(7), 1001-1009 http://dx.doi.org/10.2460/javma.243.7.1001

52. Viitmaa, R., et al (2014) Cerebral glucose utilization measured with high resolution positron emission tomography in epileptic Finnish spitz dogs and healthy dogs. Veterinary Radiology \& Ultrasound, 55(4), pp.453-461 http://dx.doi.org/10.1111/vru.12147

53. Weber, J., Maiolini, A. and Tipold, A. (2012) Evaluation of decreased glucose levels in the cerebrospinal fluid of dogs. Tierarztliche Praxis Kleintiere, 40(5) p325-332

54. Wessmann, A., et al (2010) Significance of surface epithelial cells in canine cerebrospinal fluid and relationship to central nervous system disease. Veterinary Clinical Pathology, 39(3), pp.358-364 http://dx.doi.org/10.1111/j.1939-165X.2010.00248.x 


\section{EVIDENCE \\ ochere}

\section{Intellectual Property Rights}

Authors of Knowledge Summaries submitted to RCVS Knowledge for publication will retain copyright in their work, but will be required to grant to RCVS Knowledge an exclusive license of the rights of copyright in the materials including but not limited to the right to publish, re-publish, transmit, sell, distribute and otherwise use the materials in all languages and all media throughout the world, and to license or permit others to do so.

Authors will be required to complete a license for publication form, and will in return retain certain rights as detailed on the form.

Veterinary Evidence and EBVM Network are RCVS Knowledge initiatives. For more information please contact us at editor@veterinaryevidence.org.

RCVS Knowledge is the independent charity associated with the Royal College of Veterinary Surgeons (RCVS). Our ambition is to become a global intermediary for evidence based veterinary knowledge by providing access to information that is of immediate value to practicing veterinary professionals and directly contributes to evidence based clinical decision-making.

\section{www.veterinaryevidence.org}

RCVS Knowledge is a registered Charity No. 230886. Registered as a Company limited by guarantee in England and Wales No. 598443.

Registered Office:

Belgravia House

62-64 Horseferry Road

London SW1P 2AF 